\title{
Manucho y yo: Cecil (1972) o cómo se autobiografía una metanovela ${ }^{1}$
}

\author{
Victoria Aranda Arribas ${ }^{2}$
}

Resumen. El presente artículo se cifra en el estudio de Cecil (1972), novela corta del argentino Manuel Mujica Lainez, autor de títulos tan destacados como Bomarzo (1962) o El Unicornio (1965). Con el objeto de revalorizar y dar a conocer este libro, considerado hasta el momento como una obra menor dentro de su narrativa, se presta atención al examen del relato desde dos laderas: la forma autobiográfica y la metaficción, por una parte; y el análisis narratológico del relato, por otra, incidiendo en los ecos y homenajes del Coloquio de los perros de Cervantes.

Palabras clave: Manuel Mujica Lainez; Cecil; Coloquio de los perros; autobiografía; estudios animales.

\section{[en] Manucho and me: Cecil (1972) or how to autobiography a metanovel}

\begin{abstract}
This article is aimed at studying Cecil (1972), a short novel written by Argentinian Manuel Mujica Lainez, author of noted titles such as Bomarzo (1962) or El Unicornio (1965). This work will be analysed in order to vindicate it and make it known, given that this is a book that has always been considered as a minor one in the general production of Mujica. Special attention will be paid to two concrete approaches: on the one hand, I will examine the metafiction contained in the novel and the autobiographical form in which it is shaped, and, on the other, I will tackle a narratological analysis of the aforementioned work, stressing the influence of Miguel de Cervantes and homages given to El coloquio de los perros.

Keywords: Manuel Mujica Lainez; Cecil; El coloquio de los perros; Autobiography; Animal Studies.
\end{abstract}

Sumario. 1. El sabueso de Mujica: Cecil el Encantador. 2. La perrera crítica. Teoría de una recepción. 3. El esqueleto canino: de casta (autobiográfica) le viene al galgo. 4. El esqueleto canino: de casta (autobiográfica) le viene al galgo. 5. Desviarse del camino carretero. 6. Conclusiones.

Cómo citar: Aranda Arribas, V. (2018) Manucho y yo: Cecil (1972) o cómo se autobiografía una metanovela, en Anales de Literatura Hispanoamericana 47, 413-445.

1 Este trabajo se inscribe en el marco del proyecto de excelencia I+D+I La novela corta del siglo XVII. Estudio y edición (y II) (FF FFI2013-41264-P).

2 Universidad de Córdoba, Córdoba. España.

E-mail: imberetumbra@gmail.com 


\section{El sabueso de Mujica: Cecil el Encantador}

En su Discurso crítico sobre el origen, calidad y estado presente de las comedias de España, contra el dictamen que las supone corrompidas y a favor de sus más famosos escritores el doctor Frey Lope Félix de Vega Carpio y don Pedro Calderón de la Barca (1750), Tomás de Erauso y Zabaleta -seudónimo de Ignacio de Loyola Oyanguren, marqués de la Olmeda- se hizo eco de un artificio que cierto engañador decidió someter al vago criterio de las gentes de un pueblo algo corto de luces. Un farandulero se había ufanado de mostrarles un perro metido en una jaula vistosamente adornada y, sobre ella, un rótulo en el que se rezaba: "Aquí está el famoso Serpentín del Mogol, parecido al perro español”.

Nadie se sorprenderá, en fin, de que aquellos lugareños se apresuraran a admirar tan estupenda novedad. Y menos peregrino aún resulta que, a costa de gastar su dinero, todos llegaran a la conclusión de que se trataba de un perro común según sus atributos, dado que ninguno de ellos parecía distinto de los que normalmente concurren en este animal. Pero, una vez considerada la prevención del enorme parecido con nuestros sabuesos, los curiosos pueblerinos aquietaron "el opuesto juicio, en vista de que ninguno tenía la menor noticia de aquel país remoto ni de aquel can extraño" (Erauso y Zabaleta 1750: 67). Lo que no impidió que, mientras nuestro engañador se entretenía en ponderar las cualidades del animal, las cuales cada vez lo acercaban más a las de cualquier perro español, algunos espectadores se atrevieron a dudar de su magnificencia y maravilla, a lo que él respondía impertérrito: "Nadie dirá otra cosa, no habiendo visto el Serpentín; mas yo ya he dicho que parece perro" (Erauso y Zabaleta 1750: 67). Como también parece y es perro el narrador de Cecil (1972), novela de Manuel Mujica Lainez. Dicho relato concita nuestra atención a propósito de dos claves: 1) la autobiografía canina del protagonista, con pinceladas relativas al autor; y 2) el rastro de El coloquio de los perros (1613) de Cervantes en varios de sus capítulos.

Luego, ¿qué daño supone la aceptación de la existencia de un par de gozques primorosos -Berganza y Cecil-, en virtud de la fascinación generada hace ya tres siglos por las gracias de uno de sus antepasados y herederos, respectivamente: el auténtico, real e inimitable Serpentín de Mogol?

La pertinencia de un análisis como el presente se justifica por la escasez de los de su especie. Harold Bloom (2006) no incluyó en El canon occidental ${ }^{3}$-y cabe hacerlo extensivo al resto de los cánones que en el mundo han sido, exceptuando los que abordan este tipo de obras desde la ladera de los animal studies ${ }^{4}$-a ninguna voz con los rasgos que caracterizan al "yo autor" de Cecil (1972)-. No contamos con monografías que nos descubran los entresijos de tan bizarro corpus. Sus miembros no son celebrados con exposiciones, ni tan siquiera con biografías "no autorizadas". No disponemos tampoco de excesivos datos relativos a la poética concreta - pues se trata de una suerte de subgénero- de cada uno de estos

Cito el libro de Bloom por ser el más conocido internacionalmente. Véase asimismo y sobre todo Pozuelo Yvancos y Aradra (2000).

4 Teresa Hiergeist (2016) ha investigado los aspectos de la vida cotidiana de los perros más representados en la obra cervantina. Agradezco a la autora el envío de su trabajo. Adrienne L. Martin (2013) se ocupó de la función de los animales en los espectáculos teatrales del Siglo de Oro, abundando en la información que nos facilita Berganza a este respecto. 
narradores. A decir verdad, no abundan en la historia de la literatura textos que pertenezcan a la raza del que constituye el objeto de nuestro artículo. He aquí, pues, uno de los pocos libros escritos por un perro ${ }^{5}$.

¿Podemos acaso otorgar la etiqueta de "literario” a un relato cuya autoría corre a cargo de un galgo pusilánime de nombre Cecil? ¿Qué sentido tiene arrojar luz sobre la novela de una exquisita mascota que, en principio, carece de toda racionalidad? No por casualidad, Stevenson observó que "la civilización, los modales y la moral de la estirpe perruna están subordinados, en gran medida, a la de su amo ancestral: el hombre” (Stevenson 2015: 225); por tanto, indagar sobre los canes, aunque estos sean de ficción, se me antoja, hasta cierto punto, una forma de descubrirnos a nosotros mismos. Es por ello que apenas debiera sorprendernos que Pérez-Reverte, en su recopilación de artículos Perros e hijos de perra, señale que "ningún ser humano vale lo que un buen perro [...] cuando desaparece un perro noble y valiente, el mundo se torna más oscuro. Más triste y más sucio" (2014: 120). En buena lógica, por lo que atañe a la consideración de las "obras perrunas", es probable que nos ayuden no solo a esclarecer lo más genuino de nosotros mismos, sino incluso a desentrañar el lado más noble de las personas caso de aceptarse que todos los que cultivan el arte de la crítica sean los mejores exponentes de la condición humana-.

Por otro lado, muchas novelistas de renombre, verbigracia Jack London ( $\mathrm{La}$ llamada de lo salvaje, 1903; Colmillo Blanco, 1906) o Thomas Mann (Señor y perro, 1918 $)^{6}$, han juzgado pertinente dedicar a los canes más de un volumen de mérito, lo que nos lleva a plantearnos la legitimidad de la “creación perruna”. No es de extrañar pues que Manuel Mujica Lainez consagrara uno de los libros más importantes para él a su pequeño sabueso. Y es que, según Kalmus, "autor” y protagonista de Investigaciones de un perro, "todo el saber, la totalidad de las preguntas y respuestas, está contenido en los perros” (Kafka 2000: 355).

\section{La perrera crítica. Teoría de una recepción}

Tanto el argentino Manuel Mujica Lainez (1910-1984) como su novelita Cecil han sido víctimas de un injusto capricho: la injusta relegación frente a otros cuentistas y narradores a los que la crítica ha ensalzado hasta el infinito. Varios libros de Mujica, de hecho, por lo que atañe a la investigación, todavía hoy continúan

5 A pesar del juego que planteo en este párrafo, no ignoro en ningún momento, como es natural, la diferencia de responsabilidad que existe entre el autor real (Manuel Mujica Lainez) y el autor ficticio: “Cecil”. Ambas dimensiones serán estudiadas con detalle a lo largo de este artículo. Acerca de las voces narrativas, véase Darío Villanueva, 1991a).

6 Entre los libros de tema perruno, además de los ya mencionados, cabe citar las novelas de Cervantes (El coloquio de los perros, 1613), James Oliver Curwood (Kazan, perro lobo, 1914) o Paul Auster (Tombuctú, 1999), amén de los cuentos que recoge Choin (2014): Antón Chéjov (“Kashtanka”, 1887), Mark Twain (“A Dog's Tale”, 1903), O. Henry ("Memoirs of a Yellow Dog”, 1906), P. G. Wodehouse ("The Mixer” publicado en The Man with Two Left Feet, 1917) y G. K. Chesterton (“The Oracle of the Dog”, 1926). Por último, destacan una serie de títulos cuyas voces narradoras son caninas, igual que en Cecil: los Pensées de Riquet (1904), de Anatole France; Investigaciones de un perro (1931) de Kafka; Flush (1933), de Virginia Woolf; Dormir al sol (1973) de Adolfo Bioy Casares; sin olvidar las recientes Vidas y opiniones del perro Muf y de su amiga Marilyn Monroe (2010) de Andrew O’Hagan y la Historia de un perro llamado leal (2015) de Luis Sepúlveda. 
durmiendo el sueño de los justos, eclipsados por los de los dos gigantes de las letras argentinas del siglo XX: Borges y Cortázar. Más aún: sus novelas históricas más celebradas, Bomarzo (1962), El unicornio (1965), El laberinto (1974) y El escarabajo (1982), han relegado a Cecil a la condición de cenicienta dentro de la trayectoria del autor de Misteriosa Buenos Aires.

Considerada una auténtica rareza, pero de segunda fila respecto al resto de las obras de Mujica, solo un par de trabajos otorgan a Cecil mayor fuste: el artículo “Cecil: una autobiografía novelesca de Manuel Mujica Lainez” (2014), en el haber de Choin, que examina la novelita centrándose en la información que esta nos brinda sobre la vida y personalidad del autor, sin desdeñar las claves de la trayectoria de Mujica reflejadas en Cecil; y los cinco apartados que le dedicó Quesada Portero en su tesis "Bomarzo" y el autobiografismo en la narrativa de Manuel Mujica Lainez (2010), sobre la que volveré a lo largo de este ensayo.

Asimismo, muchos de los especialistas en la narrativa de "Manucho" -como era cariñosamente conocido entre sus allegados y familiares- aluden de pasada a Cecil cuando trazan el itinerario de la producción mujiquil. Abundan en la peculiaridad de este relato, en sus tintes autobiográficos o en la evidente, si bien a contrapelo, herencia cervantina -que examina con especial atención Fernández Ariza ${ }^{7}-$, pero sin agotar todas las lecturas posibles. Baste citar por ahora los trabajos de Caballero Wangüemert (2000), Schanzer (1986), Font (1976), Francés Vidal (1986) o Piña (1986), quien, sin profundizar en exceso, devolvió a Cecil su lugar central dentro de la trayectoria del bonaerense, hasta el punto de afirmar que este opúsculo constituye un hito autónomo en el nutrido marco de temas de su corpus novelesco:

la cuarta línea discernible dentro de su narrativa, [...] El escritor y su propia inmortalidad, está constituida por una sola novela, Cecil, de 1972. Como vimos, Mujica Lainez va rescatando a través de su literatura instancias cada vez mas restringidas, [...] y en el punto final de esa pirámide invertida está él mismo, como heredero de una cultura, un país, una clase y una misión: la artística. (Piña 1986: 182)

Finalmente, otros estudiosos han tomado esta obrita como punto de partida para abordar diversos aspectos de la narrativa del argentino, en el caso de Iriarte Aristu $(1982)^{8}$, Cascón Dorado $(1999)^{9}$ y Bellini $(2013)^{10}$; o bien con un fin algo más ancilar, opción adoptada por Francia Somalo (2006), que se vale de un capítulo dedicado a Heliogábalo como modelo para la construcción contemporánea de una biografía del emperador romano a la manera de los historiógrafos latinos. Este dato pone de relieve la jerarquía de Cecil, su vuelo literario -acusadamente autobiográfico- dentro de la producción del autor de Bomarzo.

$7 \quad$ Fernández Ariza (2006) apuntó la relación entre Cecil y el Coloquio de los perros, subrayando principalmente el linaje literario de los canes protagonistas de ambas novelas, la coincidencia en ambos casos de un perro narrador, cuyas palabras pasan al texto escrito por un humano, y la presentación del "perro supersabio".

8 La autora comienza su artículo, a propósito de La casa, con una cita de Cecil acerca de los objetos de la hacienda "El Paraíso".

9 Utiliza Cecil -en concreto el capítulo de Heliogábalo- para avalar el profundo conocimiento que Mujica tenía de los emperadores romanos.

10 Cecil contribuye a engrosar la lista de obras perrunas a las que se refiere este crítico. 
Para Luis Antonio de Villena (1975: 3), amigo y devoto admirador de Mujica, Cecil no es solo una novela donde entran todos los componentes del universo literario del argentino (fantasmas, emperadores, cultura, tierra, ídolos, claroscuros), sino que la estima "como la clave mejor para entender el mundo onírico y cultural del escritor" (Villena 1979: 22). Y es que Cecil funciona como un lugar de convergencia entre la vida y el arte de Mujica: aquí se encuentran su yo público y su yo íntimo; su cotidianidad real y su realidad fantástica; los personajes ya creados, los que se quedaron por el camino, y también los que están por llegar; los momentos de inspiración y el vértigo de la sequía creativa. La amplitud de alcance de esta novelita la sitúa en un lugar de privilegio, pues nos permite entender muchas constantes del autor de Bomarzo, de sus libros y de su concepción del mundo y del arte. De ahí que se haya cartografiado a Cecil como un libro más adecuado para crítica que para los lectores, y como una novela que debiera leerse tras haber disfrutado del resto de sus ficciones (Schanzer 1986: 110).

\section{El esqueleto canino: de casta (autobiográfica) le viene al galgo}

Cecil se publicó en 1972 y pertenece a la que Francés Vidal (1986: 62-63) ha rotulado como "década inquietante" de Mujica. Sin embargo, no nos hallamos ante un texto fácil de catalogar, ya que, según Caballero Wangüemert, es esta una de las obras que "pertenecen a otras motivaciones" (2000: 28) y que se rebela, en fin, contra los límites de clasificación de acuerdo con la evolución temática de la prosa del bonaerense. A grandes rasgos, la novela retrata la personalidad de Mujica, citado siempre como "el Escritor" dentro del texto, desde el punto de vista de su perro Cecil, un selecto galgo whippet que hace gala de unas formidables fidelidad y devoción hacia su amo. El autor logra así crear una especie de Platero y yo, pero a la inversa, dado que es la mascota la que realiza una apología del dueño y no al contrario. A través de una mirada que oscila entre lo canino y lo "mujiquil", somos testigos, de la mano de tan aristocrático perrito, de los variopintos lances que se suceden en la tranquila vida que el escritor lleva en su quinta de la sierra de Córdoba.

No es esta, sin embargo, una novela que siga una trayectoria autobiográfica lineal ni tradicional -desde la infancia del autor al proceso de escritura- sino que el relato da comienzo justo en el instante en que perro y amo son presentados:

Creo que lo he fascinado y sé que él me ha fascinado también. Presumo que nos perteneceremos el uno al otro hasta que la muerte ocurra. ¿Cuál vendrá primero, desnuda, fría y alta, a visitarnos? ¿La suya, la mía? La mía, probablemente, pese a que él está lejos ya de ser un niño, porque mi vida, por inexorable capricho biológico, cuenta con un plazo mucho más corto que el acordado en general por el Destino a los de su privilegiada especie (Mujica Lainez 1975: 9);

y termina cuando el Escritor se decide a emprender una narración en la que el galgo relate su vida. Entre medias, Cecil brinda un collage de episodios que dan noticia del día a día en El Paraíso, nombre con el que el autor bautizó a su hacienda. De este modo, el galgo nos guía a lo largo y ancho de un tour por la casa 
de Mujica, orquestado por él mismo, y pasa revista, una a una, al bizarro grupo de personas (y personajes) que suelen rondarla, con episodios tan sugestivos como la muy ansiada llegada de una nueva escultura de Aquiles para el jardín.

A la vez, la visión de Cecil nos informa, por un lado, de sus hábitos más caninos y menos burgueses, y por otro, gracias al especial vínculo que lo une al Escritor, nos permite penetrar en la mente del propio Mujica. De este último artificio se derivan dos consecuencias: en primer lugar, la novela nos faculta para descubrir cómo funciona el proceso creativo del autor y la naturaleza de su relación con sus personajes, pues en el vestíbulo del relato se oculta la meditación sobre su modo de hacer novelas y la historia de la búsqueda de la inspiración, lo cual dará pie a un nuevo proyecto: el texto de Cecil; y, en segundo lugar, el whippet nos abre la puerta a la intimidad -y casi al subconsciente- del autor en las situaciones que se engarzan dentro del rosario de pequeños episodios que integran la obra; de manera que a la novela le encaja como un guante el marbete "autobiográfico” tal y como lo entendió Lejeune ${ }^{11}$, en tanto que este incide en la idea del género como historia no solo de la vida, sino también de la personalidad del autobiógrafo.

Cecil se divide en diecinueve capítulos, cada uno de los cuales retrata una anécdota de la vida en El Paraíso. Todos los episodios conforman una rutina definitoria de la vida, personalidad y cosmovisión de Mujica. Hay capítulos que nos hablan de la relación entre perro y amo (I, XIX), cada vez más estrecha; acerca de la personalidad de Cecil (II) y de las fantasías (desfilan por la hacienda antiguos o potenciales personajes creados por Mujica, como Heliogábalo o la mismísima Juana la Loca) que surgen en el “cinematógrafo” de la cabeza del Escritor y que el fino galgo presencia como testigo privilegiado (III, V, XII, XVIII):

El amor me secundaba, me franqueaba puertas, me llevaba adelante, me internaba más y más en el laberinto de su sensibilidad. Un día comprobé que cuando él miraba, yo miraba también; que cuando él leía, leía también yo; que cuando escribía, seguía yo sobre el papel, aunque estuviera a su vera, el dibujo vacilante de las palabras. [...] Estoy allí lo mismo que en ese cinematógrafo del pueblo al que me conduce en los meses fríos [...]. Sí, me sitúo -reitero que tal vez por la magia del amor- en el cinematógrafo de su cabeza. (Mujica Lainez 1975: 20)

Otras secciones atañen a los personajes (Günter, Madame Pamelá, el joven Leonardo, la gata Sara) que rondan El Paraíso (VIII, IX, X, XI, XVII), esbozando de ese modo las pequeñas aventuras en las que se ven envueltos (IV, VII, XVI). Por último, algunos apartados giran alrededor de lances que nada tienen que ver con la realidad cotidiana del autor, sino con figuras históricas o mitológicas sobre los que este trabaja o que, en un momento dado, ocupan su mente: Heliogábalo y Aquiles (XIII, XIV, XV). Conviene prestar atención a estos últimos, ya que gracias a dichos capítulos, que constituyen la mise en abyme de la novela, se activa el voyeurismo del curioso lector ante la forma en que Manucho elabora su obra literaria. Además, cabe analizar con detalle el principio y el final de la novela, pues

11 "Relato retrospectivo en prosa que una persona real hace de su propia existencia, poniendo el énfasis en su vida individual y, en particular, en la historia de su personalidad” (Lejeune 1994: 50). 
dotan de una estructura cíclica al relato, en tanto que lo último que se nos cuenta es el momento en que el Escritor comienza a redactar el libro que el lector ya ha casi concluido, copiando las primeras frases con las que Cecil introdujo la historia en la primera página del relato:

Me atrevía a empinarme a su lado y cuáles no serían mi arrebato y mi sorpresa, cuando avizoré que en la página virgen, allí donde supuse que trazaría, con firmes letras de imprenta, el título "Heliogábalo”, en vez diseñaba lentamente mi nombre, “Cecil”. [...] Contuve la respiración y lancé un suave ladrido amoroso, en tanto se armaba el párrafo inicial:

“Creo que lo he fascinado y sé que él me ha fascinado también. Presumo que nos perteneceremos el uno al otro hasta que la muerte ocurra. ¿Cuál vendrá primero, desnuda, fría y alta, a visitarnos? ¿La suya, la mía? La mía, probablemente, pese a que él está lejos ya de ser un niño...”. (Mujica Lainez 1975: 212)

Por lo que se refiere a la metodología utilizada, nuestro trabajo participa, por un lado, de las aportaciones de la Literatura Comparada, pues aquí se analizan las simetrías y los préstamos que la novela de Mujica toma del Coloquio de los perros de Cervantes; sin pasar por alto breves alusiones a otras obras pertinentes para nuestro estudio, tales como las Novelas a Marcia Leonarda, de Lope de Vega, o Cómo se hace una novela, de Unamuno, muy distantes en el tiempo, si bien emparentadas por técnicas narrativas que desbrozaré algo más tarde. Por otro lado, acudo a una serie de hitos que han venido explorando y pautando el espacio autobiográfico, sobre todo los de Lejeune (19944a, 1994b y 2004), pero también los de De Man (1991) ${ }^{12}$, Eakin $(1988)^{13}$, Fernández Prieto (2004) ${ }^{14}$ y Pozuelo Yvancos (2006). Finalmente, en la mayor parte de los parágrafos en los que se articula esta investigación se aplican asimismo los principios de la narratología con especial observancia de la taxonomía de Genette (1989).

En resumidas cuentas, me ocuparé de los que entiendo como los dos rasgos fundamentales y definitorios del libro de Mujica, y que se cifran, además, en las citas con las que él mismo abre su novela: "tu te plais à plonger au sein de ton image” (“disfrutas al zambullirte en el fondo de tu imagen”), extraída del poema L'Homme et la Mer de Baudelaire, por lo que se refiere al carácter autobiográfico del texto; y esta otra: “...desde que tuve fuerza para roer un hueso tuve deseo de hablar, para decir cosas que depositaba en la memoria...”, pronunciada por

12 "El hecho de que Lejeune use "nombre propio" y "firma" de manera intercambiable apunta, al mismo tiempo, a la confusión y a la complejidad del problema, puesto que, al igual que resulta imposible permanecer en el sistema tropológico del nombre, y de la misma manera en que se ve forzado a desplazarse de la identidad ontológica a la promesa contractual, tan pronto como la función performativa queda afirmada es reinscrita inmediatamente en constreñimientos cognitivos” (De Man 1991: 114).

13 "Critiques like these of the traditional narrative model of life history underline the central role of model in the history of autobiographical dicourse as we now conceive it: the form of an autobiography is increasingly understood as a manifestation of the autobiographer's concept of self” (Eakin 1998: 34).

14 "Pero el sujeto autobiográfico no es resultado azaroso de ese dinamismo discursivo; hay un autor que elige los modelos que mejor se ajustan a las imágenes en que desea (auto)representarse y exponerse ante los lectores. La identidad es, así, creada en y por la escritura, pero se trata de una ficción que quiere valer como verdadera, no porque reproduzca ni restaure el pasado o cualquier identidad preexistente, sino por ofrecerse como una búsqueda de ese pasado, como un ejercicio de autocomprensión y de autoconocimiento desplegado hacia otros a los que se apela, a los que se reclama una respuesta” (Fernández Prieto 2004: 21). 
Berganza en el Coloquio de los perros de Cervantes. Con ella, Manucho subraya el carácter metaficcional de esta obrita, fruto a la postre de la impronta que ejerció sobre Cecil la última de las Novelas ejemplares (1613).

\section{Zambullirse en el fondo de la propia imagen}

Es sabido que no es necesario acudir de forma obstinada a la biografía de un autor para explicar ciertos aspectos de su obra que escapan al alcance de los estudiosos. Y es que la poética de la Erlebnis anda ya de capa caída. Empero, no es en absoluto baladí fijarse en el decurso vital de un autor a la hora de tratar temas referidos al autobiografismo del susodicho; y menos aún lo es servirse de documentos que nos guíen en el afán de interpretar su pensamiento durante el período en que una obra comenzaba a conformarse en su imaginario.

En una carta a Victoria Ocampo del 3 de junio de 1971, publicada en un monográfico de la Revista Sur, en homenaje a Mujica Lainez, Manucho declaraba:

En Córdoba consagraré mi tiempo, junto a la chimenea, a estudiar a Heliogábalo. Estoy leyendo ahora el trabajo que le dedicó Artaud en 1934, erudito y personal, y, al revés de lo que calculé -pues temí que anulara por completo el plan de mi novela- me estimula a llevarla adelante. Dios (o mejor dicho los Dioses)... dirán. (Mujica Lainez 1986: 73)

En el anterior párrafo encontramos a un Mujica "pre-Cecil”, que aún no tiene ni la más ligera idea de en qué se convertirá el proyecto de su siguiente libro. Así pues, vemos que la génesis de Cecil está inevitablemente ligada a la de la fallida novela histórica -aunque triunfal relato biográfico- "Heliogábalo", que la misma novela que nos ocupa contiene en el capítulo XIV. Es durante la elaboración de este relato de ambientación romana cuando el autor empieza a embriagarse del mundo que lo rodea y a percibir el potencial de su propio estado y de su entorno como tema para una nueva obra, idea esta que irá poco a poco devorando la nonata historia de Heliogábalo. Así parece ponerlo de manifiesto en esta carta del 31 de agosto de 1971:

[...] no tengo ni la menor idea de cuándo iré a Buenos Aires. Este sitio encantado me agarra cada vez más, luego de la etapa de adaptación ya transcurrida. Soy muy feliz aquí, y tú lo comprenderás mejor que nadie. [...] Estoy reuniendo materiales para una novela de largo aliento, que completará espero- mi tríptico. Eso me exige el desvelo de mucha nota, de mucho estudio. Vivo, pues, en la actualidad, entre los romanos del tercer siglo y del imperio de un muchacho loco, Heliogábalo. Todavía no veo con absoluta claridad al personaje, pero empieza a dibujarse ya. Quizás, dentro de dos meses, pueda iniciar mi libro ${ }^{15}$. (Mujica Lainez 1975: 75).

\footnotetext{
15 La cursiva es mía.
} 
Así pues, la vida de Mujica ha de concebirse como altamente "literaturizable”, en el doble sentido de este término: como objeto y como agente, como lienzo y como soplo de inspiración. El argentino siente el impulso de escribir sobre sí al mismo tiempo que se le hace cada vez más sencillo poetizar su entorno por medio de los libros y de su refinado sentido estético y creativo:

Acá se vive algo dentro de la cotidiana realidad, y mucho dentro de la alada fantasía. El fantasma, las literarias imágenes, los parientes, se confunden en un fondo de follajes y de nubes, de tal manera que es imposible separarlos, distinguirlos, marcar los límites de un mundo y del otro. Acá uno se puede morir sin excesivo drama, porque la substantividad, la objetividad, son y no son. (Mujica Lainez 1975: 91)

Al final, cuando Manucho escribía, siempre lo hacía un poco acerca de su propia figura, y cuando vivía, siempre novelaba, aunque no lo hiciera sobre el papel:

En mi opinión el escritor es el más libre de los hombres; [...] es dueño [...] del privilegio de expresarse como se le antoje, creando, sin más socorro que su pluma sincera, la atmósfera espiritual que conceptúa necesaria. Al fin de cuentas, no obstante que disfrace a sus héroes, complique los episodios, etc., siempre escribirá sobre sí mismo. Vamos por la vida con un tema único y es necesario que nos ingeniemos para desarrollarlo sutilmente. (Mujica Lainez 1986: 68)

En virtud de esta opinión, conviene recordar cómo Cristina Piña otorgaba a Cecil el poder de constituir una línea temática independiente y auto-céntrica dentro del total de su narrativa, amén de señalar que en la obra de Manucho, y haciendo honor a su fama de dandi, el leit motiv es, en cierto modo, Él:

-Manucho es un personaje social provocador, usa chalecos vistosos y monóculos, además le encanta actuar.

- Sí, en el gran teatro de la vida. Ese teatro tiene un lado atractivo, vistoso, como usted dice refiriéndose a mis chalecos, que me divierte y también divierte a los demás.

- ¿No le ha dado miedo que el glamuroso Manucho eclipse al Mujica Lainez escritor?

-No, para eso están mis libros. Cuando escribo, Manucho queda de lado. (Roffé 2007: 107)

No debe extrañarnos, pues, que Raúl Quesada haya dedicado su tesis doctoral al estudio del autobiografismo en las obras de Mujica, acentuando la presencia de la personalidad del autor de Los ídolos y los retales de su vida en muchas de sus novelas, y, por encima de todas, en Bomarzo. Pero solo en el caso de Cecil podemos decir que se exacerba el "yo" en la producción mujiquil, y de forma de veras explícita, ya que es el único libro que se revela autorreferencial, según lo declara su autor: 
Y precisamente, quiero a ese libro porque es el único autobiográfico en su totalidad. En los otros, vos lo sabés muy bien, uno pone mucho de sí mismo en tal o cual personaje o en alguna anécdota modificada, pero en este, no. En el libro se cuenta cómo transcurre nuestra vida y mis vacilaciones al empezar una obra y mis angustias al terminarla. Se habla de aquella idea mía, en esa época, de escribir una novela sobre Heliogábalo. Se muestra El Paraíso, el clima de la casa es una visita guiada porque describo cuarto por cuarto y voy explicando la realidad de esas paredes a las que me sentí muy unido, casi supersticiosamente. (Vázquez 1983: 113-114)

Sin embargo, para Quesada, no es Cecil la novela más autobiográfica de Mujica, sino que él la interpreta más bien como un "autorretrato”. En efecto, el género de este opúsculo, y en consecuencia el nombre con que se lo designa, es aún motivo de conflicto, ya que Cecil rebasa todos los límites establecidos por lo que se refiere a la escritura del yo. Por un lado, el propio Manucho habla de “autobiografía novelesca”. Villena (1984: 10) dijo de ella que era una "semiautobiografía”. Quesada, por último, opina que también se la puede llamar "novela autobiográfica”, pues se trata de "la más cercana a los cánones clásicos de la literatura autobiográfica” (2010: 232-233), aunque no por ello la obra más vivencial de Manucho, primado que le pertenecería a Bomarzo:

La cuestión principal es que el autor, a través de este curioso narrador, se limita a hablar de su presente y, como mucho, de su pasado inmediato, desde su traslado a El Paraíso. Mientras que etapas de la vida tan importantes para la labor introspectiva, como son la niñez y la adolescencia, son ignoradas por completo. De hecho, ya señalamos en su momento que, dentro de los géneros literarios del yo, Cecil en realidad se acerca más a la fórmula del autorretrato que a la verdadera autobiografía. (Quesada 2010: 376-377)

Como ya he indicado, el autor prefiere colgarle al relato canino la etiqueta de “autorretrato”, término por el que también se decanta Schanzer (1986: 109), cuando se refirió a esta novelita como "a fictionalized self-portrait”, alegando que no puede considerarse una autobiografía "real”. Sin embargo, no podemos dejar de lado el hecho de que un autorretrato acostumbra a tener un carácter más ensayístico que narrativo, como señala Villanueva (1991b: 100), característica a la que Cecil no se ciñe de forma estricta. Además, la referencialidad, entendida como un atributo esencial de la autobiografía, no pasa de ser un ingrediente de la misma, pero no el único, ni siquiera el principal en muchas ocasiones; parto pues de la base de que el autobiógrafo no puede ofrecernos sino una versión subjetivada de su vida y que, desde el momento en que se ve filtrada por el verbo y la tinta, pasa en todo caso a convertirse en algo diferente de la realidad, de manera que la figura del yo pasa a ser una des-figura, como nos explicó Paul de Man (1991).

Todo este conflicto alrededor del género de Cecil y del cuestionamiento de su carácter autobiográfico se debe a que la novela presenta una serie de características nada convencionales: 
1. Mujica aparece como personaje, pero no como narrador de la novela, que está contada por su galgo. Han de separarse por tanto las figuras ficcionales del "autobiografiado" (el Escritor) y del autobiógrafo: en este caso, el perro Cecil. Al ser el narrador un personaje desarrollado de forma fantástica, y que a veces relata episodios de esta índole, se pone en duda la veracidad de lo contado en la obra general y, en consecuencia, su mismo carácter autobiográfico. Este último problema se ve reforzado por el hecho de que el nombre del personaje que representa al autor (Mujica) ni siquiera es mencionado de forma explícita en el texto, ya que la mascota siempre se refiere a él como "el Escritor".

2. El tema del relato es sin duda la vida del autor. Como es habitual en las autobiografías, los eventos que Cecil expone y comenta son narrados desde el presente y pertenecen al pasado, pero se trata de un pasado muy próximo, que puede incluso coincidir, más de una vez, con la composición del relato, exceptuando los casos de analepsis internas completivas.

Pero, para catalogar el libro como una autobiografía o bien desechar esta tesis, antes de nada hemos de dejar claro qué se entiende por autobiografía, dado que "la autobiografía puede ser cualquier texto o ningún texto en absoluto" (Fernández Prieto 2004: 18). Pozuelo Yvancos (2006: 24) divide la crítica de los que se interesan por este género en dos vertientes, diferenciadas desde su aparición hasta nuestros días: la primera, sancionada por Lejeune (1994a), se define por la indispensabilidad del pacto autobiográfico y de la identidad entre autor, narrador y personaje; la segunda tiene como máximo representante a Paul de Man, y es apoyada por Derrida ${ }^{16}$ y Eakin (1988). Conocida como "rama deconstruccionista", presenta una visión más laxa de lo que se puede entender por "autobiografía", en tanto que se preocupa principalmente por el problema de la identidad del autobiógrafo en el texto.

De acuerdo con la visión de la autobiografía que posee Lejeune en su primer $L e$ pacte autobiographique (1973), encontraremos una perspectiva muy limitada; tanto que a Cecil le costaría encontrar en ella su lugar, ya que en dicho trabajo el teórico galo establece una diferenciación muy estricta entre novela y autobiografía. Lejeune no deja espacio para las posibles licencias ficcionales que los autores puedan tomarse sobre su propia vida, ya que para él "la autobiografía no conlleva gradaciones: o lo es o no lo es” (Lejeune 1994a: 63). Puntualiza su definición del género cuatro requisitos adicionales para que un libro sea considerado autobiografía (Lejeune 1994a: 51): a) ha de ser una narración en prosa, b) el tema tiene que girar en torno a la vida individual, la historia de una personalidad; c) identidad entre el autor -en tanto que persona real-y el narrador; d) identificación del narrador con el personaje principal y visión retrospectiva del relato.

Cecil cumple, pues, las dos primeras premisas para ser aceptada dentro del grupo, pero la c) y la d) hacen tambalear su entidad como autobiografía, tal como la concibe Lejeune. En efecto, por un lado, en Cecil el autor -como persona real-

16 Jaques Derrida (2009: 55): “La firma de la autobiografía se escribe con ese paso. Sigue siendo un crédito abierto y solo remite a uno de los dos yo [je], contrayentes sin nombre, a través del anillo del eterno retorno. Esto no impide, al contrario, permite que aquel que dice "soy mediodía en pleno verano" ("Por qué soy tan sabio”) diga también “soy un doble”: y, por lo tanto, no me confundo -todavía no- con mi obra”. 
no se identifica con el narrador, pero sí con el personaje principal. Por el otro, el personaje principal no coincide con el narrador, al menos no en primera instancia.

No obstante, hemos de considerar que cuando el libro toca a su fin, la historia que hemos venido leyendo se revela como aquella que el autor comienza a escribir; por lo tanto, el papel del narrador se hace ambiguo y la negación de su identidad con Mujica Lainez deja de ser tan drástica como parecería en un principio. Además, sabemos que, por medio de la telepatía que une a Cecil con el Escritor, tenemos acceso a la mente de este último, como si fuera este último el que expresara sus propios sentimientos:

Ya basta del salón grande. Como siempre, los amaestrados perros, mis congéneres comicastros, partiquinos, me amargan la visita. Los veo saltar locamente en la memoria del Escritor. (Mujica Lainez 1975: 35)

Aparecen, de tanto en tanto, periodistas: cada vez menos, porque ya ha dejado de ser "noticia” [...]. Al principio les intrigaba el porqué de ese alejamiento. [...] No comprendían, en lo que a mi amo respecta, su necesidad de apartarse, a esta altura del camino, de las sendas demasiado transitadas, para que ese otro "smog" que es la novelera bruma no le impidiese ver con lucidez dentro de sí mismo. (Mujica Lainez 1975: 43)

En el capítulo V (“Los fracasos el Escritor”), leemos de primera mano sus pensamientos acerca de sus personajes y su reciente falta de inspiración, gracias al pretexto de que el Escritor había expresado por escrito su parecer a este respecto, con el fin de que los periodistas no lo malinterpretaran si le preguntaban por este asunto:

Hay una etapa de mi vida de escritor singularmente angustiosa: es la que se estira entre la terminación de un libro y el comienzo del siguiente. Como ese lapso empezó cada vez que puse fin a una obra, son ya muchos los períodos arduos que he debido atravesar. [...] Recuerdo que cuando puse la palabra 'fin' en mi dilatada novela del Renacimiento italiano, luego de más de dos años de redacción, me sobrecogió el desconsuelo de que ya no volvería a escribir, tanto había puesto de mí mismo en sus 650 páginas ${ }^{17}$. (Mujica Lainez 1975: 45-47)

Dentro de la clasificación del francés en cuanto a narraciones que cuentan una vida, la novelita de Mujica se afiliaría al subgénero de la llamada "biografía en primera persona” u "homodiegética” (Lejeune 1994a: 55). Sin embargo, como ya se ha dicho, la identidad de la aristocrática mascota no es tan fácil de separar de la de su amo alto-burgués. Además, no es esta una biografía al uso, porque la vida que se está contando es la del autor del libro. Asimismo, el "contrato de lectura” que funciona para Cecil no es ninguno de los pactos cerrados que propone Lejeune -autobiográfico o novelesco-. Como expliqué antes, el personaje de Mujica en el

17 Al igual que Mujica evita dar el nombre del personaje (El Escritor) que es dueño de Cecil, también da no pocos rodeos a la hora de referirse a sus propias obras literarias, ya que nunca menciona el título concreto de ninguna, como ocurre en este caso con Bomarzo. El argentino juega a la ambigüedad para no caer en la banalidad -e incluso en la presunción- de la evidencia, del exhibicionismo creativo. 
libro siempre es evocado bajo el sobrenombre de "el Escritor" y, ya dentro del libro, el autor no explicita la naturaleza del pacto que vamos a firmar con él. Sin embargo, de forma extratextual, Mujica sí que ha afirmado su identidad con el Escritor, del mismo modo que son reconocibles el resto de personajes y el espacio por sus nombres verdaderos, como los de la familia y el entorno cercano de Manucho ${ }^{18}$. Luego no habría ninguna duda: nos hallamos ante una autobiografía, si bien para Lejeune quizás se trataría de "un juego al que no se juega con intenciones serias" ${ }^{\prime \prime}$.

Sin embargo, no podemos dejar de mencionar los hechos que convierten a esta obra en merecedora del "pacto novelesco", y es que una parte de los eventos que se nos cuentan no pueden ser referenciales, como tampoco su narrador real puede ser un perro. Estos subterfugios pertenecen sin duda al campo novelesco, lo que problematiza de nuevo la tipología de Cecil. No obstante, existe un factor clave para Lejeune y es el de que la autobiografía posibilita la verificabilidad de lo narrado (Pozuelo Yvancos 2006: 29). En el relato de Manucho, esto se hace posible en la medida en que taracea la pura ficción con eventos no fantásticos sacados de su propia experiencia: la frustración del Escritor/Mujica, la llegada al Paraíso de la estatua de Aquiles, el interés por Heliogábalo, etc. De ello dejan constancia sus cartas y varias de sus entrevistas.

Por consiguiente, convendrá huir un poco del corsé terminológico de Lejeune, como de hecho haría la teoría posteriormente, y asignar a esta pieza un lugar intermedio entre el pacto autobiográfico y el novelesco ${ }^{20}$, con lo que se le ajustaría como un guante la definición genérica que su mismo creador, máxima instancia autorial por lo que a su obra se refiere, le otorgó: Cecil es una autobiografía novelesca. Sin más.

Con la llegada de la posmodernidad, el género autobiográfico se renueva, toma prestadas técnicas de la novela, se vuelve profundamente metaliterario y provoca una serie de cambios: tanto en la crítica, que ha sabido adaptarse a su progresiva metamorfosis, como en los lectores, que han aprendido a distinguir la verdad de la ficción dentro de una historia en la que aparecen mezcladas, sabedores de que el autor ya no se lo dará todo hecho. Como afirma Fernández Prieto, con los años, los autobiógrafos han sido conscientes de su yo ficticio y del propio género al que contribuyen, adoptando multitud de técnicas de la novela:

18 Philippe Lejeune (1994a: 65), diferencia dos formas de indicar que el libro pertenece al género autobiográfico: implícitamente (por el título del libro o con una sección inicial en la que se aclara este dato) y de manera categórica (coincidencia de nombres e identidades). Aquí tampoco se contempla la forma en que Mujica da a entender el autobiografismo de su novela.

19 El crítico francés afirma que "en una autobiografía declarada, y dejando de lado el caso del seudónimo [del autor y no del personaje], ¿puede tener el personaje un nombre diferente al del autor? No parece posible; y si, por un efecto artístico, un autobiógrafo eligiese esta fórmula, siempre le quedarían dudas al lector: ¿no está leyendo simplemente una novela? En estos dos casos si la contradicción interna fue elegida voluntariamente por el autor, el texto que resulta no es leído ni como autobiografía ni tampoco como novela, sino que aparece como un juego de ambigüedad pirandelliana. A mi entender, es un juego al que no se juega con intenciones serias" (Philippe Lejeune 1994: ${ }^{\text {a. }}$ 71). Aunque este no sea en puridad el caso de Cecil -pues en el caso del otro nombre que recibe el personaje que representa a Mujica, este no pasa de ser en realidad un apodo (Escritor), ya que el nombre auténtico se obvia-, me ha resultado curiosa la opinión reticente de Lejeune a la hora de aceptar como legítimo un texto que escapa a sus clasificaciones y a su valoración del concepto de ambigüedad, un punto restrictivo.

20 Aunque niegue a Cecil su poso autobiográfico, así lo cree también Quesada (2010: 246). 
Los textos, por su parte, acentuaron su dimensión autorreflexiva y metaautobiográfica, tematizando el propio proceso de escritura y los problemas de identidad, y muchos ensayaron estrategias para alterar y romper los moldes narrativos asociados a la tradición realista e historicista. Conscientes a cada paso de las trampas de la memoria, los tropos del lenguaje, las tramas que urde la narración, la multiplicidad de un yo diseminado en un haz de desdoblamientos especulares, prefirieron el fragmentarismo y el desorden a la linealidad, la alternancia de personas gramaticales al dominio de la primera, la subordinación de la cronología histórica a la temporalidad de la memoria. (Fernández Prieto: 19)

Como vemos, Cecil encaja a la perfección en este grupo de autobiografías de nuevo cuño, en tanto que se puede considerar una meta-autobiografía en toda regla. En efecto, en esta obra no vamos a encontrar una simple retrospección en la vida del autor contada por él mismo; en primer lugar, como anticipábamos, los hechos que se narran pertenecen al pasado, sí, pero a un pasado no tan lejano como el que se nos presenta en otros libros del mismo género. La novela fue escrita entre 1971 y 1972 y sabemos por las cartas a Victoria Ocampo, por ejemplo, que su interés por Heliogábalo se avivó por los mismos años. Es por ello que Quesada afirma que

estos tiempos de la historia y del discurso que terminan asimilándose, son también una peculiaridad de dos modalidades de escritura del yo distintas de la autobiografía propiamente dicha, a las que ya hemos aludido en otra ocasión: el autorretrato y el diario íntimo. [...] Es como si el escritor hubiese hecho de este librito un híbrido de tres tipos diferentes de literatura introspectiva, autobiografía, autorretrato y diario, para conocerse mejor y darse a conocer en la intimidad de El Paraíso. (Quesada 2010: 450)

No obstante, el hecho de que los episodios narrados sean recientes no tiene por qué restar carácter autobiográfico al libro. Si bien las descripciones y las costumbres que Cecil relata pertenecen al presente del autor, los eventos puntuales (la irrupción de Leonardo, la llegada de la estatua de Aquiles, el estudio de Heliogábalo, la visita a las cuevas pintadas, etc.) sí se inscriben en el pasado, aunque este sea un pasado próximo. Hemos de tener en cuenta además la presencia de analepsis internas, como adelantábamos antes: las anécdotas sobre Alemania (Mujica Lainez 1975: 101-103), el día en que los dueños de la quinta adquieren a Cecil, etc.

Es cierto que la novela que nos ocupa no proporciona apenas información sobre la infancia y la trayectoria profesional del Escritor hasta 1971 (año en el que Cecil empieza a escribirse), pero el escaso uso que el autor hace de la retrospectiva viene motivado por una razón: en vez de concentrarse en los recuerdos, Manucho se recrea en una suerte de semblanza literaria de sí mismo en el presente, o sea, en el resultado de dichos recuerdos. En otras palabras: Cecil nos confirma que, en el posmodernismo, la autobiografía deja de ser mímesis para convertirse en poiesis (Villanueva 1993), y aquí tienen cabida las innovaciones temporales, las experimentaciones relacionadas con el punto de vista y la inclusión de elementos ficcionales en la historia. 
La elección de circunscribir el relato a este momento se relaciona además con el desdoblamiento del autobiógrafo. Como ya he señalado, la identidad en la autobiografía es una de las cuestiones que más interesa a la vertiente deconstruccionista, ya que el distanciamiento que provoca el hablar de un "yo pasado" tiene como consecuencia la duplicidad del autor, que es, por un lado, la persona real y la que escribe desde el momento presente, y, por otro, aquella de la que nos habla, es decir, el objeto, el personaje. Y la (re)construcción de la identidad de este personaje es, como no podría ser de otro modo, subjetiva.

Pero en Cecil este desdoblamiento se complica lo suyo. Mujica, el autor, aparece en la novela como personaje (el Escritor), en efecto, pero no como un personaje a la manera del Je est un autre de Rimbaud, ni tampoco como el que analiza Pozuelo (2006) a propósito de las autobiografías de Caballero Bonald (Tiempo de guerras perdidas, 1995; y La costumbre de vivir, 2001), donde el personaje surge de la diferenciación entre "el yo evocador y el yo evocado", sino que aquí el personaje que relata (el canino relator) es diferente de aquel que se evoca: el Escritor. La causa de esta desvinculación reside justamente en el tiempo narrado: como los hechos a los que Mujica alude son recientes, el personaje que le representa -el Escritor- no es para sí mismo un objeto al que pueda juzgar y describir con claridad, porque coincide con su "yo presente", por lo que necesita un elemento que le otorgue el distanciamiento del que le priva la cercanía cronológica, de ahí que decida utilizar la mirada de alguien que no es él, pero al que se encuentra unido "por el cordón umbilical de la correa roja” (Mujica Lainez 1975: 70): su galgo Cecil ${ }^{21}$.

En palabras del propio Manucho,

los Cárcano, Miguel Ángel y su mujer, me regalaron un perrito muy jovencito, que se llama Cecil [...]. Sé que me quiere; cuando llego de buenos Aires, por ejemplo, las fiestas son muy grandes, pero después vuelve a su timidez. [...] Un día se me ocurrió hacer una novela donde él contara mi vida en El Paraíso, artificio que me permitía decir una serie de cosas, que de otro modo no hubiera podido escribir; hubiera sido de una vanidad espantosa. Igual he sido muy criticado. (Vázquez 1983: 113)

Pero al mismo tiempo que crea a un actor para que haga de sí mismo, es inevitable que Mujica ponga mucho de sí en el propio narrador. El whippet comparte numerosos rasgos con su amo, haciendo de este su alter ego y la más fina demostración de ese tópico que reza que los perros se parecen a sus dueños (o viceversa). Además, no olvidemos que el libro comienza y termina con las mismas palabras: solo que en la primera página el mensaje es emitido por la voz (escrita) de Cecil y al final por la escritura del propio Manucho, a lo que hay que sumar aquí

21 "La perspectiva de distanciamiento provoca la sugestión de la duplicidad, la alteridad necesaria para entrar sin prejuicios en esa esfera autobiográfica de la "verdad", que es asimismo ficción fantástica, tan fantástica como la esfera del diálogo de los insomnes conversadores cervantinos” (Fernández Ariza 2006: 116). En este sentido, según Font (1976: 20): “el recuerdo permite al narrador asumir un punto de vista narrativo omnisciente editorial con ciertas limitaciones y así establecer simultáneamente, con habilidad, un distanciamiento y un acercamiento estético (subraya el aspecto ficcional de la narración y sumerge al lector en el dato biográfico) que facilita la coexistencia de la fantasía y la realidad”. 
el hecho de que los dos compartan pensamientos, ya que está unidos por la telepatía, fruto del amor que se profesan. Se potencia así una imagen de "perrohombre", ya que los dos protagonistas de la historia se encuentran fundidos en un mismo personaje que se desdobla en dos en la narración: una simbiosis entre amo y mascota que se apura hasta las últimas consecuencias.

Por otro lado, además de la identidad del Mujica real, del Escritor de la novela y del mismo Cecil, hemos de tener en cuenta la imagen de Manucho como figura pública, ya que su peculiar carácter era conocido y comentado en la sociedad argentina, por lo que es algo que cualquier lector tendrá en la mente al iniciar la lectura de su autobiografía:

-Usted ha dado la imagen de ser un hombre mundano, frívolo, despreocupado por todo lo que no fuera su entorno sociocultural; alguien, además, que parece sentir placer aterrorizando a la gente con ironía y sarcasmos. ¿Cómo es realmente?

-Creo que soy un hombre esencialmente bueno, pero dotado de un tipo de ingenio innato que, a veces, me obliga a decir cosas que parecen impropias de un hombre bueno. Pero esas cosas si las digo son, también, por bondad, porque las digo para divertir a los que están a mi alrededor. Y soy un artista en el sentido de que veo todo con ojos de artista, [...], desde el punto de vista de la historia del arte. Detrás de cada cuadro veo muchos otros cuadros de los que he visto en galerías y museos; detrás de cada ser humano reconozco a muchos otros que he visto en libros de Balzac, Dickens, Shakespeare, Mark Twain. (Roffé 2007: 116)

Así, durante toda la novela y conforme dota de relieve a su personaje, Mujica deja que descubramos su verdadero yo. Como argumenta Choin (2014: 38), "se va delineando, página tras página, el verdadero carácter de Manuel Mujica Lainez. No asoma nunca el personaje público, el alter-ego creado para afrontar el estruendo mediático y mundano de la capital”. Mujica no es Manucho, es ante todo un hombre embebido en los libros y en lo que escribe, un ser cuyo hábitat se sitúa en la frontera entre la fantasía y la realidad. Manuel Mujica Lainez es el Escritor. El libro le sirve para dar a conocer y perpetuar esta imagen de sí mismo, una autobiografía que viene a ser el máximo exponente del "art of self-invention” de Eakin.

Pero, independientemente del nombre que le apliquemos ${ }^{22}$, lo de veras relevante es el reconocimiento de la originalidad e innovación en el género de una obrita como Cecil, la cual, en definitiva, tiene el objetivo de "crear la vida y la identidad de un yo a través de una escritura que es a la vez espejo engañoso y apuesta por la verdad" (Fernández Prieto 2004: 21). Es Cecil una obra que nos invita a descubrir a un Mujica genuino y diferente, una puerta de acceso a su intimidad, a su mente y a

22 Veo necesario apuntar que Cecil tampoco podría ser catalogada como “autoficción”, ya que se entiende por esta "un relato cuyo autor, narrador y protagonista comparten la misma identidad nominal y cuya denominación genérica indica que se trata de una novela” (Alberca 2004: 237). La verdad es que esta denominación no se aleja mucho de la primera teoría autobiográfica del propio Lejeune allá por 1973 (1994a)), al implicar la determinación de un marbete para asignárselo a un género que para el teórico francés quedaba anónimo: la autoficción es propia de un libro en el que el personaje/narrador coincide con el autor, pero que se desarrolla en el marco de la ficción. Como hemos dicho, los hechos que se suceden en Cecil no son puramente ficción y el nombre del personaje no se explicita en coincidencia con el del autor. 
su manera de crear, sin que importe demasiado -y a él menos que a nadie- la forma genérica que utilicemos para referirnos a ella. Después de todo, what's in a name?

\section{Desviarse del camino carretero}

-¿Cómo se siente cuando termina de escribir un libro? -Como despojado. El vacío lo supero cuando surge una nueva idea, otra historia, otros personajes a los que sospecho les dedicaré la siguiente novela. (Roffé 2007: 107)

Del anterior diálogo se deduce, como de tantas otras declaraciones de Manucho, que escribir es para él tanto o más importante que desenvolverse en la vida real. Luego no será extraño que su autobiografía esté inevitablemente tintada por la meditación sobre las letras -la introspección a la hora de crear sus universos y relatar sus historias- como parte fundamental de su vida. Es aquí donde entra en acción el plano metaficcional que marca y enriquece la novelita que nos ocupa. Este rasgo se nos revela de forma explícita en la última página, cuando Cecil lee las primeras frases del libro que el personaje de Mujica por fin se decide a escribir, las cuales coinciden del todo con las primeras líneas del texto que acabamos de leer. Así pues, hemos sido testigos durante todo el libro de la génesis de la obra que acabamos de concluir: la historia ha relatado su propio nacimiento. Y, como apunté más arriba, al volver a leer el párrafo de arranque. Dicho fragmento se le aparece ahora al lector como algo más que diferente de aquello que le había sugerido en una primera lectura, como si del Quijote del Pierre Menard de Borges se tratara:

Me atrevía a empinarme a su lado y cuáles no serían mi arrebato y mi sorpresa, cuando avizoré que en la página virgen, allí donde supuse que trazaría, con firmes letras de imprenta, el título “Heliogábalo”, en vez diseñaba lentamente mi nombre, “Cecil”. [...] Contuve la respiración y lancé un suave ladrido amoroso, en tanto se armaba el párrafo inicial:

“Creo que lo he fascinado y sé que él me ha fascinado también. Presumo que nos perteneceremos el uno al otro hasta que la muerte ocurra. ¿Cuál vendrá primero, desnuda, fría y alta, a visitarnos? ¿La suya, la mía? La mía, probablemente, pese a que él está lejos ya de ser un niño...”. (Mujica Lainez 1975: 212)

Esta técnica no puede sino recordar a la del Diálogo de la lengua de Juan de Valdés, por citar un ejemplo bien conocido, en tanto que en dicha obra ya se empleaba el recurso de plantear el inicio del libro en el momento en que este termina $^{23}$. A raíz de este sortilegio que ambas obras -me refiero a Cecil y al coloquio del humanista español- comparten, puede aplicársele a la perfección al texto de Mujica las palabras que Laplana Gil dedicó a la obra valdesiana, afirmando que es esta una obra “que convierte en literatura el acto mismo de la

23 "PACHECO: [...] Avéis de saber que lo que todos os pedimos por merced es que, tomando esto que está anotado de lo que aquí havemos hablado, lo pongáis todo por buena orden y en bueno estilo castellano [...]”. Vid. Valdés (2010: 273). 
creación literaria, un cervantismo avant la lettre, que revela el reverso de la trama del texto literario a la vez que nos muestra el anverso del tapiz” (Laplana Gil 2010: 36).

Así pues, tras ser testigos de este fenómeno, los atentos lectores se plantean en ambos casos cómo se ha producido la fijación del texto: ¿es el perro el que ha configurado las frases que hemos leído y que, por tanto, el autor ha plasmado tal cual han surgido de su canino intelecto o, por el contrario, este las ha reelaborado después de percibir la visión del galgo? Y, en el caso de Valdés, ¿fue Aurelio, el copista escondido, el que escuchó, tradujo y escribió la conversación que sostuvieron el mismo Valdés, en calidad de personaje, Marcio, Coroliano y Pacheco, tal y como salió de sus respectivos labios, antes de verterla al español porque conversaron en italiano- de forma simultánea? O, por el contrario, ¿estamos leyendo la posterior traducción de Juan de Valdés? Así se introduce el problema de la oralidad vs. literatura en el Humanismo renacentista. Estos detalles ya provocaron ciertas preguntas sobre la propia enunciación de la obra del conquense, poniendo el acento en la metaescritura de su relato.

Como se ha apuntado, aparte de retratar la vida del autor, queda claro que, en el fondo, Cecil narra una historia de la búsqueda de inspiración y una reflexión acerca del oficio de escritor. Cecil nos muestra, a través de no pocos recursos formales y argumentales, lo intrincado de elaborar un discurso, de reconstruir un rosario de sucesos a través de la palabra, hecho este que la emparenta con una de las novelas más señeras de nuestras letras: El coloquio de los perros ${ }^{24}$. Como indica Ruiz Pérez, el planteamiento de Cervantes “supone llevar la atención del lector, antes que al enunciado del narrador, al acto mismo de la enunciación, comenzando por el hecho sorprendente de que ésta corresponda a un perro” (Ruiz Pérez 2008: 412) ${ }^{25}$.

Por un lado, la herencia textual cervantina en Cecil se hace palpable a través de la cita del Coloquio que encabeza el texto, y la huella de Cervantes en la producción del argentino recurre a menudo entre los críticos ${ }^{26}$, quienes acostumbran a aducir cuatro obras en particular: Glosas Castellanas (1936), Don Galaz de Buenos Aires (1938), El laberinto (1974) y, por último, Cecil. En la primera, la analogía con la obra cervantina se puede apreciar desde el mismo título. La segunda se compone en cambio de una serie de ensayos sobre el Quijote y de escenas que podrían añadirse a la novela real, verbigracia la muestra de cómo transcurre la vida de Sancho en la aldea después de la muerte de don Quijote. En El laberinto, la madre del niño protagonista, el Ginés de Silva que nos mira desde el interior de El entierro del conde de Orgaz del Greco, no es sino la protagonista de La ilustre fregona de las Novelas Ejemplares.

Por otro lado, la caracterización del Coloquio como metaficción ha sido más que aceptada por los especialistas, detalle en el que coincide sin duda con Cecil. Además, no puede pasar desapercibido el enlace más obvio entre ambas novelas: el

24 En dicho caso, además, vuelve a asomar el citado problema del discernimiento entre la oralidad y la escritura: ¿es el Coloquio el fruto de la copia pasiva por parte de Campuzano del discurso que los perros pronunciaron palabra por palabra?

25 El mismo Ruiz Pérez (Ruiz Pérez 2008: 412) indica además que el Coloquio y el Diálogo de la lengua comparten el procedimiento del testigo oculto (Campuzano y Aurelio, respectivamente).

26 Cfr. Fernández Ariza (2006); Castellino (1994); Rafael Recio Vela (2005); Schanzer (1986); y Caballero Wangüemert (2000). 
protagonismo canino. Pero dejando esta evidencia a un lado, una serie de rasgos vinculan ambas obras desde el punto de vista narratológico $\mathrm{y}$, en especial, del estatuto ficcional.

Como sabemos, en el Coloquio de los perros, que no puede analizarse al margen de El casamiento engañoso -relato que le precede y sirve de marco narrativo-, el alférez Campuzano, ingresado en el Hospital de la Resurrección de Valladolid a causa de la sífilis, copia en un cartapacio la conversación (el Coloquio) que cree oír entre dos perros y que le da a leer a su buen amigo el licenciado Peralta. En ella, uno de los alanos, Berganza, haciendo las veces de narrador, cuenta su vida, mientras que el otro, Cipión, lo escucha y de vez en cuando ataja su discurso. Se pueden distinguir tres narradores dentro del relato (Hermosilla Álvarez 2008): en primer lugar, se nos presenta un narrador heterodiegético ${ }^{27}$, primer responsable de contarnos el encuentro entre Campuzano y Peralta. Llegados a este punto, Campuzano ejecuta el papel de narrador homodiegético con focalización interna al contar su propia historia al licenciado Peralta, o sea, su narratario.

A continuación, Peralta lee el cartapacio donde Campuzano transcribió la plática de los perros de Mahúdes, convirtiéndose de este modo el alférez en una especie de autor ficticio o de recopilador (a la manera del Montalvo de Amadís de Gaula) de la novela ejemplar que constituye el Coloquio ${ }^{28}$. Dentro de este nuevo nivel metadiegético, asoma un tercer narrador homodiegético, también con focalización interna: Berganza, cuyo narratario es el perro que lo acompaña, o sea, Cipión. Se establece, por tanto, un paralelismo entre la situación narrativa del plano intradiegético y del metadiegético a través de la aparición de dos narradores homodiegéticos que se dirigen a sus respectivos narratarios: Campuzano y Peralta; Berganza y Cipión.

\section{COLOQUIO \\ EXTRADIÉGESIS}

(1) Narrador extradiegéticoy heterodiégetico

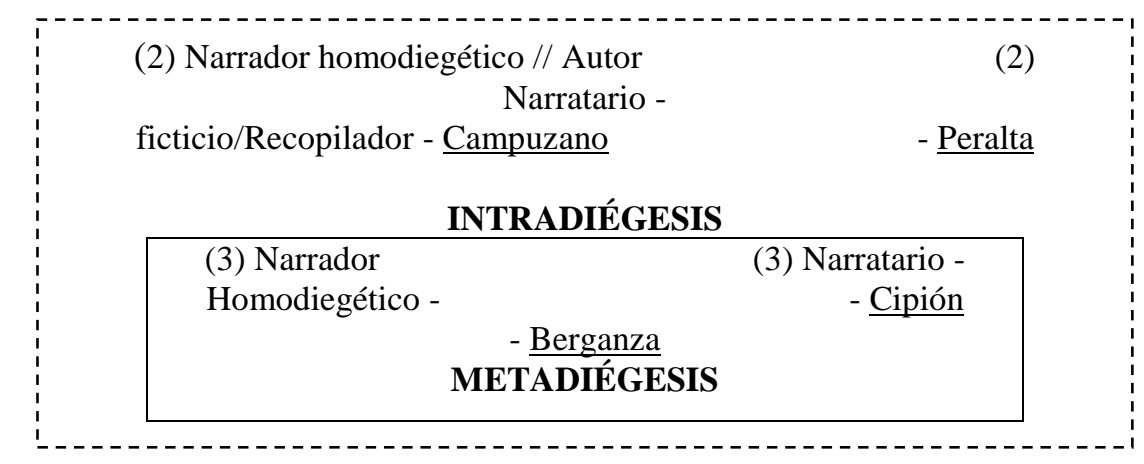

27 Utilizaré, a zaga de Álvarez Hermosilla (2008: 225-266), la nomenclatura de Genette tanto para la focalización como para los tipos de narradores y niveles narrativos.

28 La doble función de este personaje viene dada por el hecho, ya comentado, de que no queda claro para el lector si el mensaje que recibe es elaborado por él mismo o simplemente es el producto de una copia no intervencionista. 
La traslación del esquema narratológico de una novela respecto a la otra no se hace evidente, pero deriva de la figura compartida del autor ficticio/recopilador de un relato canino que desempeñan, por un lado, Campuzano, en la obra cervantina y, por el otro, el Escritor, en la de Mujica Lainez. La primera diferencia que encontramos entre ambas estructuras se cifra en la ausencia de un primer narrador heterodiegético, ya que la autobiografía del bonaerense comienza con un narrador que se expresa en primera persona (homodiegético): su perro Cecil. La focalización de este primer enunciador también se presenta problemática, ya que no encaja en la clasificación establecida por Genette: Cecil conoce tantos sus propios pensamientos como los del autor gracias a la conexión mental existente entre ambos, por lo que nos hallamos ante una suerte de focalización interna común, ya que el perro, alter ego del Escritor, comparte la visión del amo. Al poder comunicar finalmente el relato de la novela que Cecil ha ido narrando al Escritor, este se convierte en el narratario final de su discurso, aunque no podemos obviar que durante todo el libro Cecil se dirige a un "tú" que equivale al lector ficticio, cuyo papel nos corresponde a nosotros, sus lectores, Peraltas contemporáneos en esta perruna historia de la posmodernidad.

Una vez analizado este primer plano intradiegético, toca ahora enfrentarse a un segundo problema: hasta el momento no parece que exista otro nivel narrativo dentro del libro, lo que llevó a Fernández Ariza (2006: 114) a afirmar que "es evidente que Mujica prescinde del marco narrativo cervantino”. Sin embargo, si indagamos un poco más en la estructura de Cecil, obtendremos algunas respuestas plausibles acerca de esta discrepancia formal. El último párrafo del relato, al que ya he aludido, equivale, como por arte de magia, al íncipit del relato que acabamos de leer (“Creo que lo he fascinado y sé que él me ha fascinado también...”). Teniendo esto en cuenta, el propio libro -y no necesariamente su narrador ni tan siquiera ninguno de los personajes- crea la historia-marco de la ficción con la que dicho texto se liga, hasta el punto de trasuntarse en una especie de “perro novelado”, por no decir que en una novela canina, por los cuatro costados además.

CECIL

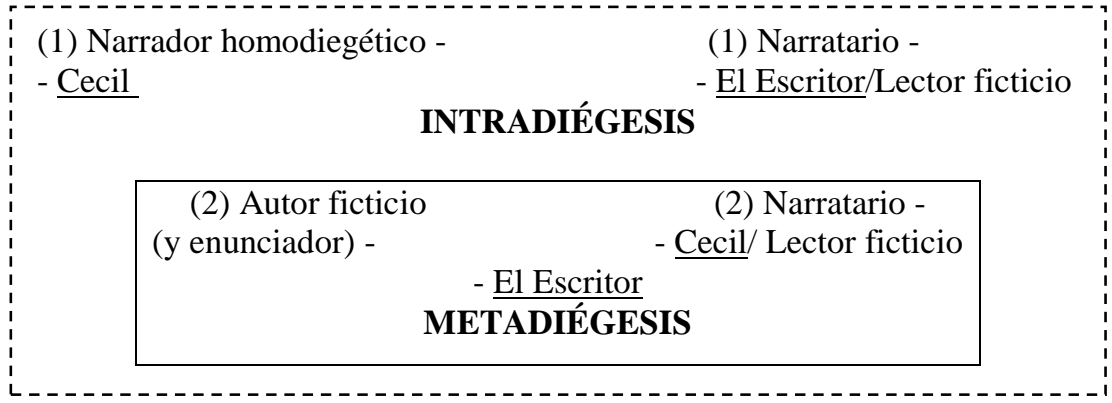

Además, del mismo modo que en la novela-cornice de Cervantes la enfermedad del alférez, el ambiente de confusión del hospital y la posibilidad de que lo escrito haya sido un sueño apuntalaban definitivamente la verosimilitud -esto es, la suspensión del descreimiento y el "pacto ficcional” ante la circunstancia de que sostengan un diálogo dos seres que carecen del "divino don del habla” (Cervantes 
1991: 563 ${ }^{29}$-, la recreación de un mundo que se sitúa entre la fantasía y la realidad dentro de la cotidianidad del Paraíso, donde habitan fantasmas y por el cual deambulan varios personajes de otros libros del autor ("la abuela del marqués de Sade", "los hidalgos reunidos en el entierro del conde Orgaz", "Aquiles y Patroclo", "la reina loca” (Mujica Lainez 1975: 54-55), así como la descripción de la telepatía entre la mascota y el amo, nos facilitan los datos suficientes para que terminemos de aceptar la legitimidad de los eventos narrados. Dicha legitimidad, además, queda zanjada cuando el perro-autor manifiesta su indiferencia acerca de la probable incredulidad del lector ante los sucesos de apariencia poco realista que él mismo ha descrito.

En este sentido, hay dos comentarios pertenecientes a sendos libros que merecen ser examinados en conjunto, ya que ambos implican una especie de permisión ficcional, de licencias que los autores consienten ante la descripción de un hecho del todo ajeno a la realidad que no pueden terminar de justificar. En el caso de Cecil, tras explicar que ese intercambio psíquico es la razón por la que el perro se interna en la cabeza del amo gracias al amor que se profesan, y siendo consciente de lo poco verosímil que podría resultarnos este medio de relación, el galgo concluye que

esto es lo más similar a una explicación que se me ocurre. Los de afuera, los otros, naturalmente no captarán una interpretación tan extraña. A menos -cosa rara- que se trate de auténticos enamorados. Yo no puedo expresar sino lo que siento, y aquí está. (Mujica Lainez 1975: 21)

Del mismo modo, frente a la incredulidad de Peralta ante un hecho tan insólito como el de que hablen dos perros, Campuzano había apunta:

Pero, puesto caso que me haya engañado, y que mi verdad sea sueño, y el porfiarla disparate, no se holgará vuesa merced, señor Peralta, de ver escritas en un coloquio las cosas que estos perros, o sean quien fueren, hablaron? (Cervantes 1991: 557)

Volviendo al análisis de los niveles narrativos y de sus narradores, es importante señalar la complejidad (meta)ficcional de lo que Manucho logra en esta novelita, menor en apariencia. A la luz de lo expuesto, se ve de forma clara que nos adentramos por la caja china de una historia marco que contiene otra, ya que Cecil nos cuenta cómo el autor empieza a escribir su novela. Pero, realmente, ¿cuál es el plano intradiegético y cuál el metadiegético? ¿Cuál es la historia marco y cuál la que se micro-injerta en su interior? ¿Acabamos de leer los pensamientos de Cecil o lo ya urdido por el Escritor? Todas estas preguntas encuentran su razón de ser en el hecho de que la narración marco y el relato metadiegético comprenden la misma historia, lo que conduce a un laberinto infinito de planos ficcionales al más puro estilo de Borges, donde los personajes intercambian continuamente sus papeles narrativos dentro de la novela.

29 Citaré siempre por esta edición. 
Así pues, podemos entender que la narración a la que hemos asistido a lo largo de la novela es en realidad el plano metadiegético introducido de forma abrupta y que no se demuestra como tal hasta el final del mismo libro. Además, si contemplamos la escena en la que Cecil lee las primeras palabras que el autor escribe al final en su cuaderno, entrecomilladas y a las que siguen unos puntos suspensivos que simbolizan el resto del libro, el perrito se convierte en el nuevo narratario, al igual que Peralta se convertía en el narratario de lo escrito en el cartapacio por ese autor ficticio que es Campuzano. Así pues, al establecer una identificación entre los participantes de cada nivel narratológico como se pudo hacer en el caso del Coloquio, esta vez el papel de narrador de Cecil, nuevo narratario, pasaría al del Escritor y viceversa.

El perro se zambulle en el interior del texto de Mujica, que, en principio, ha escrito Cecil; traspasa, por tanto, el espejo entre la realidad (que para nosotros ya era un truco: ¡un perro que habla!) y la ficción, por decirlo al modo de Alice in Wonderland, rompiendo así la frontera entre el presente desde el que Cecil apela a los lectores y todo lo que les narrará enseguida: unos hechos que, paradójicamente, él mismo protagoniza y sucedieron mucho antes, o quizá después, porque, al final, Mujica Lainez comienza la redacción de una novela que nosotros ya hemos leído desde la perspectiva, la pluma y la prosa de su perro.

De este modo, el cuadro diegético expuesto anteriormente se vuelve reversible:

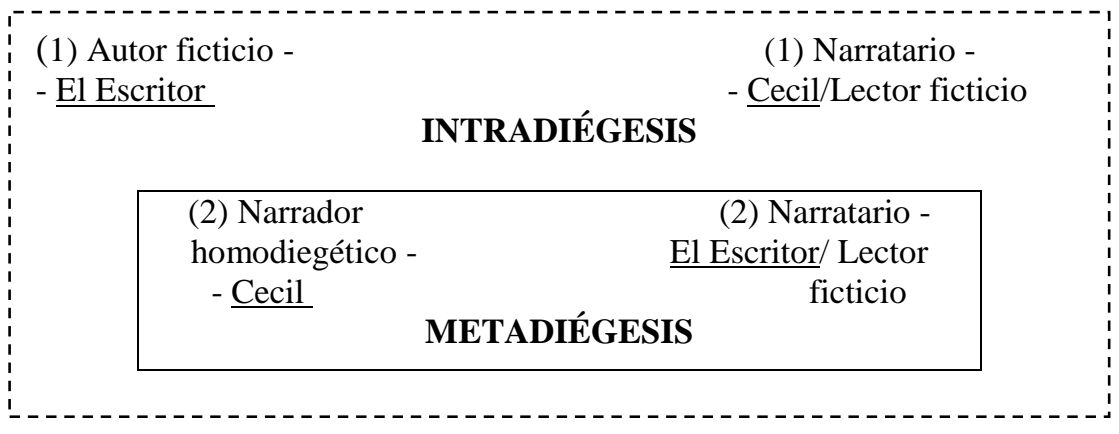

Luego el paralelismo estructural entre ambos narradores puede equipararse de forma casi simétrica, reforzando el parentesco entre ambas novelas.

Por otro lado, en la novela ejemplar, fruto de las interrupciones del discreto Cipión ${ }^{30}$, que le exige a su interlocutor que no abuse de los paréntesis (“Basta, Berganza; vuelve a tu senda y camina" (Cervantes 1991: 571), sigue tu historia y no te desvíes del camino carretero con impertinentes digresiones; y así, por larga que sea, la acabarás presto" (585)), Cervantes “desafía conscientemente las pautas aristotélicas. [...] Las llamadas al orden de Cipión a su hermano vienen a confirmar, en su fracaso, la querencia digresiva del hablar y del narrar” (Fernández Prieto 2008: 208).

30 Utilizo aquí el adjetivo “discreto” con todas las connotaciones que le asigna Da Costa Vieira (2011: 109). El “discreto” es el cortesano, ser agudo, ingenioso y racional, pero quien, además, también vigila los mecanismos de producción del discurso: “Cipión, a su vez, gracias a su discreción funciona como regulador ético y poético del trazado de la historia de Berganza [...]. Cipión representa la prudencia que, como dice Castiglione, "es la compañera de todas las virtudes”“. 
Asimismo, Da Costa (2011: 108) señala que es Cipión quien hace posible la metaescritura,

lo que corresponde en este contexto al acto de analizar, ponderar y criticar la enunciación de Berganza, teniendo en cuenta no sólo los efectos que producen su relato sino también sus mecanismos de producción en el sentido de detectar sus recorridos digresivos.

Es justo este detalle lo que parece que llama la atención de Mujica a la hora de tomar la novela ejemplar como base de un relato propio. Incluso se diría que coincide en su adopción con lo que, recientemente, el novelista Javier Marías (2013: 55-56) ha elogiado de la colección cervantina, a la que, por otra parte, le niega algo de pan y no pocas de sus sales:

Y acaba teniendo uno la impresión de que lo que mejor se le daba a Cervantes era lo que aún hoy muchos juzgan lo más "impropio” de las novelas y cuentos, [...]. Es decir, la digresión el brujuleo, el hilo roto o suelto, el inciso, el excurso, la reflexión [...], la errabundia, el salto de un asunto a otro, incluso el abandono caprichoso de una línea argumental que parecería exigir su continuación y su clausura, su "redondez" y su término, para la satisfacción de los lectores que solo desean saber qué pasó y cómo acabó todo, de los más convencionales [...]. Hablar, hablar, discurrir es el gran don o regalo, y también la gran maldición y peligro; de ellos se dan cuenta en seguida los perros Cipión y Berganza.

Con otras palabras: si Berganza, en el Coloquio de los perros, taracea su discurso con frecuentes intercolunios, en Cecil es el mismo Escritor quien a través de la reflexión y el ejercicio de su forma de novelar, interrumpe a cada paso su relato (o el del propio perro, si es que uno no es el reflejo del otro). Así pues, nos topamos con una serie de capítulos que se desvían del nudo principal: los episodios XIII (“Oriente, Grecia y Roma”), XIV (“Historia del emperador Heliogábalo”) y XV (“Aquiles en la isla de las mujeres”).

Los dos primeros se centran en el interés que suscita Heliogábalo en el Escritor (XIII) y en la enunciación de una lista de las obras gracias a las cuales Cecil y el mismo Escritor se documentaron para reconstruir la vida del emperador romano y de su plasmación literaria, que nos llega a través de Cecil pero que se relata tal y como la compuso el Escritor, marcada con letra cursiva (119-155). En el capítulo $\mathrm{XV}$, Cecil da rienda suelta a la historia que se esconde detrás de una nueva escultura que -como otro personaje- llega al Paraíso para habitar el jardín de la quinta y que despierta un gran revuelo entre sus moradores.

Como vemos, estos incisos interrumpen el fresco de la cotidianidad de la vida de Mujica y poco tienen que ver con ella; no obstante, aunque paralizan la acción central, son esenciales para descubrir los mecanismos de creación del novelista argentino y, además, sirven de lanzadera metaficcional, a la zaga de los hallazgos narrativos ya vislumbrados en el Coloquio. A través del capítulo XIII, nos adentramos en el método que sigue Mujica a la hora de escribir una novela histórica y en el XIV, asistimos, en cambio, al resultado de esta investigación, a la vez que el autor ensaya un prototipo de “biografía a la latina”, esto es, un proyecto 
en que se borra "la frontera entre la biografía histórica y la biografía novelada" (Francia Somalo 2006: 155).

Así pues, en el capítulo dedicado a Heliogábalo, el autor ofrece una biografía de un personaje histórico que le fascina y adolece de cierta falta de estudio. Para legitimar la veracidad de lo que relata, aporta una amplia bibliografía sobre el tema, pero, justo como fruto de la magia que este personaje sugiere a Mujica, es inevitable que el autor invada de nuevo su texto y que el telón historiográfico caiga en virtud del alumbramiento de la interpretación legendaria, a pesar de que esta nos haya sido presentada antes como "una biografía estricta, despojada de imaginativos alardes” (Mujica Lainez 1975: 119). Es lo mismo, por cierto, que hace con su propia autobiografía, o sea, con esa novela marco que atiende por Cecil. Además, como señala Francia Somalo (2006: 156), "la historiografía en Roma [...] fue eminentemente personalista, volcada hacia el personaje en concreto", que es lo que persigue Mujica en su "Historia del emperador Heliogábalo". En este capítulo, al igual que ocurre en Cecil en general, nos topamos con un Mujica que recicla y en parte redefine géneros clásicos, burlando o ignorando, consciente o inconscientemente, las fronteras que median entre ellos:

Y no es novela, en efecto, pero [...] tampoco se puede considerar historiografía, porque lo impide el imaginativo tratamiento [...], tanto de los detalles pintorescos como de la interpretación, que están mucho más cerca de la libertad del novelista, todavía más que la expresa voluntad de acometer ese género. (Francia Somalo 2006: 167)

En el episodio dedicado a Aquiles, a raíz de la exaltación suscitada por la llegada de una nueva escultura para su quinta, Mujica reconstruye la historia del personaje de Homero durante su estadía en la isla de Skyros, donde el héroe de la Ilíada, obligado por su protectora madre, finge ser una mujer para no verse forzado a acudir a la guerra de Troya, dado que se le había profetizado su muerte en ella. El rey de la ínsula, Licomedes, vivía en ella únicamente rodeado de sus hijas, con una de las cuales Aquiles emprende un idilio que perdurará hasta que Ulises y los suyos, tras su desembarco en Skyros, descubran su verdadera identidad.

Este episodio ya se había retomado en varias ocasiones durante el Barroco. Así, en nuestra tradición destacan El Aquiles (1612) de Tirso de Molina; El caballero dama (1640) de Cristóbal de Monroy, cuya edición crítica acomete en la actualidad el profesor Paolo Pintacuda; y El monstruo de los jardines (1653), de Pedro Calderón de la Barca. La historia no difiere en exceso de unos autores a otros: en todos los casos aparecen personajes que no constan en el resto de las obras y varía en ellas principalmente la importancia que se concede a Ulises. Cambia en las tres piezas dramáticas el nombre con el que se conoce al Aquiles travestido: "Nereida", en el caso de Tirso; "Aurora”, en el de Cristóbal de Monroy; y "Astrea”, en el de Calderón. Los tres autores introducen además un pretendiente que Aquiles, celoso, siente como una amenaza, y del que Mujica prescinde: Lisandro, el duque Segismundo y Lidoro respectivamente. Asimismo, el parentesco entre el rey Licomedes y Deidamia cambia según la obra que leamos, pues son padre e hija tanto para Tirso como para Mujica, pero hermanos para Monroy y Calderón. De igual modo, cambia el origen inventado de la dama que pide entrar en la isla, no 
coincidiendo en ninguno de los textos españoles con el del argentino, quien dice que fingió ser la hermana de Aquiles. En estas piezas, además, al no explicitar el encuentro carnal entre los dos personajes, tampoco se menciona el fruto de dicha relación que sí recoge Mujica: un niño de nombre Pirro o Neoptólemo, dependiendo de las fuentes.

En las tres comedias del Siglo de Oro se introducen personajes característicos del teatro de aquella época en un intento de adaptar la historia clásica a las expectativas del público al que iban dirigidas. Así, sobresalen los personajes de "graciosos" tanto en El Aquiles (Garbón) como en El caballero dama (Pistolete). En esta última, además, Cristóbal de Monroy decide situar la historia en un alcázar de España, donde las jóvenes casaderas son recluidas hasta encontrar marido. También en la intriga del dramaturgo sevillano, y lo propio ocurre en El monstruo de los jardines, se representa la tendencia del rey Licomedes o del prometido de Deidamia hacia Aquiles cuando lo ven con indumentaria femenina, acrecentándose de ese modo el enredo. Por otro lado, hay un motivo que se mantiene constante en todas las versiones, incluyendo la del escritor argentino: la aparición de las joyas de Ulises como determinantes para desenmascarar al travestido.

Aparte de las licencias que se puede tomar un narrador a la hora de novelar frente al espacio, más restringido, del dramaturgo, Mujica se las arregla para remozar y estética esta antigua historia. Valga como ejemplo la evolución de la amistad entre Deidamia y el Aquiles dama, tratada con bastante precaución por los autores del Siglo de Oro, que se aseguran de lograr que la bella Deidamia quede prendada del héroe como varón antes de verlo convertido en doncella:

Corrió el tiempo y Deidamia y su nueva amiga fueron inseparables. Hechizaban e inquietaban a la niña las caricias de su adquisición; el entusiasmo con que le refería, cuerdas en mano, las proezas de Aquiles; los besos con los cuales sellaba sus canciones. Esos besos, esa intimidad, eran mil veces preferibles a los que mantenía con sus hermanas. ¡Qué rara y cosquilleante desazón! [...] Los rozamientos, los arrumacos y las ternezas subieron de punto, hasta el día en que Deidamia palpó la verdadera condición de su bonita camarada. (Mujica Lainez 1975: 166)

Más allá de nuestras fronteras, ya Eurípides se había ocupado de contar lo sucedido en Skyrioi -obra que por desgracia no se conserva- y, mucho después, Dante mencionó la historia en el Purgatorio de la Divina Comedia, sin olvidar que Marguerite Yourcenar ofreció su propia versión en Achille ou le mensonge (1936). Así pues, Mujica hace suyo un tema ya tratado y modelado por distintos autores para ofrecernos una lectura más que personal. En el capítulo XV, Mujica desarrolla un tema ya clásico, al igual que hará con el Coloquio de los perros, si bien en este caso no le interesa tanto la historia en sí como su forma y juegos narrativos.

Con la inserción de este capítulo y del dedicado a Heliogábalo -pequeñas novelas dentro de esa metanovela corta que es Cecil-, y de nuevo en las partes dedicadas a discursos propios, escuchados y citados por el perro para alentar y reflejar pensamiento de Mujica -el Escritor-, el autor interrumpe la trama central para potenciar los rasgos de metaescritura, uno de los elementos fundamentales de su autobiografía. 
Se antoja forzoso, pues, remitir a dos obras señeras donde las digresiones y la reflexión sobre el arte de escribir afianzan la clave de bóveda de la narración: Novelas a Marcia Leonarda (1621-1624), de Lope de Vega, y Cómo se hace una novela (1927), de Unamuno. En la primera, la trama se ve continuamente interrumpida, pero esta vez no por el receptor, sino por el mismo autor del relato que, "por un lado, rompe las leyes poéticas de Aristóteles y, por otro, interrumpe la historia para justificar sus procedimientos” (Rabell 1992: 43), aunque la figura del narratario (Marcia Leonarda, en la colección del Fénix) se hace imprescindible como razón primera de los intercolunios o paréntesis del autor.

Por su parte, la metaficción que encierra la novela unamuniana queda explícita en el propio título. Unamuno pretende o finge escribir una novela sobre "cómo se escribe una novela”, utilizando la historia de un lector, Jugo de la Raza, trastornado por un libro; pero su razonamiento se ve continuamente interrumpido por las ideas de Unamuno acerca del exilio o del panorama social, político e intelectual de España $^{31}$. Sin embargo, que el autor nunca llegue a cumplir con el supuesto primer objetivo de su obra, debido a sus continuos paréntesis, es también una forma de emitir un mensaje acerca de la complejidad del arte de la novela, y este es el mismo caso que hermana a todas las obras mencionadas a lo largo de nuestro artículo:

Y ahora, ¿para qué acabar la novela de Jugo? Esta novela y por lo demás todas las que se hacen y no que se contenta uno con contarlas, en rigor, no acaban. Lo acabado, lo perfecto, es la muerte y la vida no puede morirse. El lector que busque novelas acabadas no merece ser mi lector; él está ya acabado antes de haberme leído. (Unamuno 2005: 208)

Tampoco hay que perder de vista el hábil rescate de una tradición anterior, de la que también se había nutrido Cervantes. En efecto, el autor del Quijote hizo suyas las hormas de la novella italiana, del diálogo renacentista, de la sátira menipea ${ }^{32}$ y de la picaresca, pero optó por no atenerse del todo a sus pautas. Como afirma Hermosilla Álvarez (2008: 232),

lo relevante en estas novelas cervantinas no es el influjo de la tradición literaria anterior [...], sino la significación que adquieren aquellos aspectos en los que nuestro autor se distancia de los modelos utilizados. Y no solo nos referimos a detalles concretos, como el uso de la predicación [...], sino a una concepción

31 Al tomar estas bifurcaciones, Unamuno (2005: 190; 195; 197; 202; 207) se ve constantemente impelido a retomar la trama de la novela que está contando: “volvamos, pues, a la novela de Jugo de la Raza, la novela de su lectura de la novela”: "volvamos a la novela de mi Jugo de la Raza, de mi lector a la novela de su lectura, de mi novela”; “pero interrumpo esta novela para volver a la otra”; “y he aquí que por última vez volvemos a la historia de nuestro Jugo de la Raza”; “voy a volver por una última vez, después de que dije que no volvería a ellos, a mi Jugo de la Raza”.

32 Según Ruiz Pérez (2011: 10), “el novelesco problema de construirse el personaje, se traslada a la retórica cuestión de construir un relato, de ordenar un discurso. Y es en este punto donde el inicio del relato picaresco estrecha sus vínculos con la tradición satírica, sumando al sentido pragmático de la crítica la inventio de un mundo degradado y la dispositio de una estructura en sarta, donde los episodios se engarzan con una tendencia no siempre orientada a la búsqueda de la unidad orgánica de personaje y relato. De la Antigüedad grecolatina procedía el mundo marginal pintado con los colores expresionistas por Petronio en su Satiricón, así como los elementos y la traducción de Erasmo y directamente evocados en el coloquio entre Cipión y Berganza”. 
personalísima de la novela que a menudo hace chirriar los postulados en los que se asientan las diferentes aproximaciones críticas.

También Mujica, como ya se ha señalado, apreció el Coloquio y se embarcó en un juego genérico dentro de Cecil que le permitía distorsionar una modalidad, como es la autobiográfica, para elaborar un libro que destaca por su heterogeneidad y originalidad.

Aunque, como afirma Fernández Ariza (2006) ${ }^{33}$, ambos narradores caninos son perros supersabios, no son del todo iguales, y por ello nos interesa contrastarlos. Para empezar, el origen de Berganza y el de Cecil son antitéticos: mientras que el primero proviene del arrabal, el segundo se afana en defender su señorial linaje. Berganza comienza su relato de esta forma:

Paréceme que la primera vez que vi el sol fue en Sevilla y en su Matadero, que está fuera de la Puerta de la Carne [...] Primero, has de presuponer que todos cuantos en él trabajan, desde el menor hasta el mayor, es gente ancha de conciencia, desalmada, sin temer al Rey ni a su justicia. [...] Pero ninguna cosa me admiraba más ni me parecía peor que el ver que estos jiferos con la misma facilidad matan a un hombre que a una vaca [...]. (564)

Además, recordemos la posibilidad de que tanto Berganza como Cipión fueran hijos de una bruja y de que quedaran transformados en perros al nacer. En cambio, Cecil, ya en el segundo capítulo de su relato, se enorgullece de su honorable raza y se enerva ante la posibilidad de un pasado mestizo:

Soy un whippet. Eso, estrictamente: un whippet. [...] Era ese - y lo es- mi apellido. Me llamo Cecil Whippet; acaso mereciera llamarme Lord Whippet o sir Cecil Whippet. De ahí mi canina vanidad. [...] La embajadora de Italia, tomando el té en la quinta, me pasó la mano por el lomo, me observó largamente y declaró: -Yo conozco a estos perros [...]. Son los descendientes del dios Anubis, los mismos que figuran en los jeroglíficos [...]. Sir Cecil, tataranieto de los seres supremos de Egipto, hijos de Osiris: ese soy yo. Y por favor, no discutamos más. (Mujica Lainez 1975: 16-18)

Tampoco hay que ignorar la relación de los perros de Mahúdes con los cínicos a través, por ejemplo, de la crítica de la murmuración ${ }^{34}$. Asimismo, Berganza, como

33 "La presentación del perro supersabio se ha mantenido con la cautela exigida por el canon de la novela ejemplar, de manera que los rasgos sobresalientes de estos héroes singulares arrojan paralelismos ineludibles”. (Fernández Ariza 2006: 114-115)

34 Según Sáez: "No se olvide que la etimología de “cínicos” en el Coloquio equivale a "perros murmuradores”, a partir del término griego kyno. En su diálogo, los perros se muestran conscientes de su condición de comentadores de la sociedad y de sus críticas. Conocen bien los límites de la murmuración y Cipión reprende a su compañero cuando incurre en este vicio, mas sin mucho éxito. Riley mantiene que el cinismo de los canes en su crítica social representa "los mejores atributos de los antiguos maestros", esto es, de los fundadores de la corriente y no de sus seguidores [...]. Los perros defienden una serie de valores alejados del mundo cínico (caridad, humildad, fe cristiana y conformidad) y al final del relato se unen significativamente a Mahúdes. No en vano la preocupación moral por la sátira (legítima e ilegítima) y la crítica es constante en su obra, y [a Cervantes] le dolían los dardos que recibía de otros escritores, pero la ambigüedad, la insinuación y la moderación de corte horaciano esquivan una lectura unívoca” (2014: 156). 
buen pícaro, ha ido pasando de mano en mano, y de amo en amo, a los que, como es lógico, no siempre debió fidelidad. El galgo, en cambio, no puede imaginar la vida sin su dueño, a quien ama por encima de todas las cosas.

El entorno en el que se encuentran nuestros protagonistas también difiere lo suyo y resulta de veras determinante. Berganza y Cipión reflejan una realidad ambigua y de dudosa moralidad ${ }^{35}$; Cecil, por le contrario, no siente nada más que amor por el mundo circundante. Tanto es así, que a la hora de imaginar el Cielo, lo hace de esta guisa:

Imagino el Cielo como una sublimación de la quinta, con cuantos quiero alrededor [...]. Un cielo en que la madre del Escritor no me diera galletitas, para mí conservadas en su ropero; un Cielo sin las Tías, sin Humberto, sin Miss Noli, sin Miel (¡vaya!); sin garrapatas, para que la mujer del Escritor me las quitase [...]; sin el cotidiano despertar en el dormitorio de mi señor; sin él, sin él ¿̇ería Cielo acaso? (Mujica Lainez 1975: 183-184)

En definitiva, Berganza encarna la figura de un perro pícaro y Cecil es cualquier cosa menos un rufián. Sin embargo, cabe resaltar que el aristocrático galgo hace gala de un detalle indispensable para que un pícaro sea considerado como tal: el relato de una vida, aunque esta no sea la suya propia. Al fin y al cabo, también en lo que al Coloquio se refiere, "cuando Berganza cuenta su vida, más que hablar de sí mismo, lo hace de otros personajes o grupos sociales” (Hermosilla Álvarez 2008: 243).

Por último, a la luz de lo expuesto en este parágrafo, se comprueba el carácter fresco y original de ambos relatos. Mientras que Cervantes crea un texto (ya clásico) de enorme modernidad, Mujica confecciona una narración profundamente posmoderna, que hunde sus raíces, por lo que se refiere a los episodios de Aquiles y Heliogábalo, en los clásicos griegos y latinos. El Coloquio cervantino, cuya vigencia va derrotando las limitaciones del olvido -ante las cuales tantos otros han caído-, ya ha evidenciado su categoría de obra inmarchitable: a su zaga, Cecil eligió como mapa y punto de partida -pero no solo- el relato de Cervantes; quién sabe si también alcanzará a seguir sus huellas por la senda de la atemporalidad.

\section{Conclusión}

Como he procurado evidenciar, esta novelita de Mujica Lainez -nada menor dentro de su producción- debe reivindicarse y analizarse con renovados bríos por los siguientes motivos:

1. Cecil constituye una fuente genuina de conocimientos para entender la figura de Mujica Lainez. Su lectura es una forma de adentrarnos en ese mundo que el Escritor habita y que nos sitúa entre la realidad y la fantasía. El autor se abre ante sus lectores y nos ofrece sus pensamientos de primera mano, intentando

35 Como afirma Fernández Prieto: "los perros han leído, han observado mucho antes de llegar al hospital de la Resurrección. Y su perspectiva es descreída y satírica. Apenas moralista. Habitan un mundo al revés en el que todo está alterado, distorsionado por el engaño, los fraudes, la hipocresía” (2008: 217). 
despojarse en parte del traje público que él mismo se había cortado. Este concepto es clave para poder entender mejor el sentido, no solo de sus libros, sino también de la gestación de los mismos. La metaficción, que se desliza por esta novela corta gracias a los capítulos sobre Aquiles y Heliogábalo, es un atributo indispensable a la hora de retratar la vida de Mujica, un artista para quien escribir, crear, novelar, en definitiva, era tan importante como vivir. O incluso más.

2. Pero el valor de Cecil no ha de circunscribirse tan solo a lo que es capaz de aportarnos en cuanto al estudio de su creador, sino que esta novela se afirma como un objeto de estimación literaria. Su originalidad cristaliza, en primer lugar, en la forma de autobiografía escogida por el autor, que es capaz de rebasar todos los límites de catalogación que impuso Lejeune y que participa, en buena medida, de la nueva corriente autobiográfica defendida por deconstruccionistas como De Man. La forma autobiográfica del libro de Mujica está marcada por:

2.1. El uso de un narrador homodiegético (el perro Cecil), que cuenta la vida de Mujica al tiempo que se muestra capaz de compartir ideas con él. Al no ser el mismo autor el que cuenta su vida en el plano ficcional, en parte porque no se explicita en ningún momento su nombre dentro del relato, alienta la duda sobre su pertenencia al género autobiográfico.

Sin embargo, la equivalencia entre el perro, fruto del acceso que este último tiene a la mente del autor, y la representación de un estado y de la narración de unos hechos que pertenecen a la existencia de Mujica avalan el marbete autobiográfico, si bien en esta obrita la veracidad se encuentra, como ya he reiterado, fusionada con la fantasía. Pero, al fin y al cabo, este es también un rasgo altamente definitorio de la vida a cuya representación asistimos:

Aún no he desentrañado por qué se afianza tanto en esta zona la tendencia a lo legendario. ¿ Será por la avanzada edad de muchos de sus habitantes quienes, como consecuencia de la memoria indecisa y de las amontonadas lecturas que los años y la soledad suponen, hacen de la realidad y de la irrealidad un solo amasijo? (64)

2.2. El relato de una serie de hechos que pertenecen no tanto al pasado del autor como a su presente. Este dato pone en jaque la retrospección, elemento imprescindible dentro de la definición de autobiografía que ofrece Lejeune, y motivo por el cual algunos críticos, como -Quesada y Schanzer-, han querido catalogarla como un autorretrato, sin tener en cuenta el carácter ensayístico de aquél y el más narrativo de este relato. En efecto, los hechos narrados no pertenecen al pasado remoto de Mujica Lainez, ni nos relata su vida desde la infancia, sin dejar por ello de ser eventos reales que ya han sucedido, más o menos nítidos en un pasado todavía próximo. Para subsanar la poca distancia que existe entre el Mujica que escribe y el personaje que lo representa, y al que dibuja dentro de su texto, el autor decide utilizar a su mascota a guisa de narrador que le otorgue dicha distancia, a la vez que 
permite que los lectores penetren en la intimidad de Manucho. Con este ardid, el autobiógrafo consigue desdoblarse de forma estricta en dos personajes totalmente diferentes, tan distintos que ni siquiera pertenecen a la misma raza, y a la vez muy iguales, ya que el can no es sino un alter ego de su querido amo.

3. Por último, Mujica remoza el esquema narratológico de Cervantes en el Coloquio de los perros. Lo que le interesa al argentino de la última de las Ejemplares no es tanto la historia cuanto la innovación narrativa del complutense, creando así un paralelismo entre los niveles de diégesis de ambas obras y de sus formas de digresión, que despliegan un mensaje metaliterario sobre la dificultad de narrar. De forma más obvia, se da una equiparación entre los narradores de los respectivos relatos, ya que, en los dos textos, se trata de perros que cuentan una vida. Cecil pasa así a revelarse como otro de los títulos de Mujica en los que se puede apreciar la influencia que el escritor del Quijote ejerció sobre él, sumándose así a las Glosas Castellanas, Don Galaz de Buenos Aires, Bomarzo o El laberinto. Manucho se revela, en fin, como un narrador capaz de apreciar -al tiempo que los apura- los vestigios del Siglo de Oro en la literatura hispanoamericana del siglo XX.

Si John Banville (2016) ha interpelado a otro perrito con pedigrí artístico, como el que asoma el hocico por el cuadro de Goya conocido como Perro hundido:

Dado que tu creador, un anciano hastiado con la crueldad y estupidez del mundo, no te dio un título, puede que esté en lo cierto al pensar que no te encuentras, como dicen la mayoría de los entendidos, atrapado en la arena, sino que estás viendo la corrida [...]. Espero que sea así y que no estés enterrado hasta el cuello en la arena, sin esperanza de escapatoria o rescate,

confiemos en que el exquisito Cecil tampoco quede sepultado y sin posibilidad de salir al ruedo crítico. Por la sola razón de que este galgo descendiente de Anubis, noble, literato, tímido, celoso y enamorado, tanto como su propio dueño, un Escritor más que pintoresco, aristocrático, irónico, imaginativo, sensible, ingenioso y legendario, no merece ser presa de esa maldición de "la minoría" de la que hablara Salinas (1981), ni mucho menos víctima de tan perro olvido.

\section{Referencias bibliográficas}

Alberca, Manuel, "La invención autobiográfica. Premisas y problemas de la autoficción”, en Celia Fernández Prieto (ed.). La autobiografía en España: un balance. Madrid: Visor, 2004.

-El pacto ambiguo. De la novela autobiográfica a la autoficción. Madrid: Biblioteca Nueva, 2007.

Banville, John, “Querido perrito”, El País Semanal, 19 de junio de 2016. Disponible en: http://elpaissemanal.elpais.com/columna/querido-perrito/

Bellini, Giuseppe, "El coloquio de los perros en algunos autores hispanoamericanos (siglos XX-XXI)”, Ínsula, 799-800 (2013), pp. 25-28. 
Bloom, Harold. El canon occidental. Barcelona: Anagrama, 2006.

Caballero Wangüemert, María. Novela histórica y posmodernidad en Manuel Mujica Lainez. Sevilla: Universidad de Sevilla, 2000.

Cascón Dorado, Antonio, “El escarabajo de Mujica Lainez en la Roma de los Césares”, en José Vicente Bañuls Oller, Juan Sánchez Méndez y Julia Sanmartín Sáez (eds.). Literatura Iberoamericana y Tradición Clásica. Barcelona: Universidad de BarcelonaUniversidad de Valencia, 1999, pp. 121-126.

Castellino, Marta Elena, "El juego de los espejos. Presencia de Cervantes en la obra de Manuel Mujica Lainez”, en Cervantes: Actas del Simposio Letras del Siglo de Oro español. Mendoza: Universidad Nacional de Cuyo, 1994, pp. 327-340.

Cervantes Saavedra, Miguel de. Novelas ejemplares. Ed. de Florencio Sevilla Arroyo y Antonio Rey Hazas. Madrid: Espasa Calpe, 1991, pp. 543-558.

Choin, David, “Cecil: una autobiografía novelesca de Manuel Mujica Lainez”, Káñina. Rev. Artes y Letras de la Univ. Costa Rica, XXXVIII, 2, 2014, pp. 27-41.

Da Costa Vieira, Maria Augusta, "La discreción de Cipión”, en Vubha Maurya y Mariela Insúa (eds.). Actas del I Congreso Ibero-Asiático de Hispanistas Siglo de Oro e Hispanismo general (Delhi, 9-12 de noviembre, 2010). Pamplona: Publicaciones digitales del GRISO/Servicio de Publicaciones de la Universidad de Navarra, 2011, pp. 101-111.

De Man, Paul, “La autobiografía como desfiguración”, Anthropos, 29 (suplemento) (1991), pp. 113-118.

Derrida, Jaques. Otobiografías: la enseñanza de Nietzsche y la política del nombre propio. Buenos Aires-Madrid: Amorrortu, 2009.

Eakin, Paul John, "Narrative and Chronology as Structures of Reference and the New Model Autobiographer”, en James Oney (ed.). Studies in Autobiography. New York: Oxford University Press, 1988, pp. 32-41.

Erauso y Zabaleta, Tomás de (marqués de Olmeda). Discurso crítico sobre el origen, calidad y estado presente de las comedias de España, contra el dictamen que las supone corrompidas y a favor de sus más famosos escritores el doctor Frey Lope Félix de Vega Carpio y don Pedro Calderón de la Barca. Madrid: Imprenta de Juan de Zúñiga, 1750.

Fernández Ariza, Guadalupe, 2006 “Manuel Mujica y Miguel de Cervantes”, en Guadalupe Fernández Ariza (coord.). Literatura Hispanoamericana del siglo XX. Mímesis e iconografía. Málaga: Universidad de Málaga, 2006, pp. 91-120.

Fernández Prieto, Celia, “De qué hablamos cuando hablamos de autobiografía”, Quimera, 240, 2004, pp. 18-21.

—_Las colas del pulpo”, en Julián Jiménez Heffernan (ed.). La tropelía. Hacia “El coloquio de los perros”. Tenerife: Artemisa Ediciones, 2008, pp. 199-224.

Font, Eduardo. Realidad y Fantasía en la narrativa de Manuel Mujica Lainez (1949-1962). Madrid: José Porrúa Turanzas, 1976.

Francés Vidal, Sorkunde. La narrativa de Mujica Lainez. Bilbao: Servicio Editorial de la Universidad del País Vasco, 1986.

Francia Somalo, Rosa, "La tradición latina de la biografía”, en Guadalupe Fernández Ariza (ed.). Literatura Hispanoamericana del siglo XX: Historia y Maravilla. Málaga: Universidad de Málaga, 2006, pp. 155-174.

Hiergeist, Teresa, "Del perro en Berganza. El Coloquio de los perros desde una perspectiva zoopoética”, en Mechthild Albert, Ulrike Becker, Rafael Bonilla Cerezo, Angela Fabris(eds.). Nuevos enfoques sobre la novela corta barroca. Frankfurt am Main: Peter Lang, 2016.

Iriarte Aristu, Julia, “Mujica Lainez y los objetos”, Boletín Millares Carlo, 6 (1982), pp. 327-336. 
Kafka, Franz, “Investigaciones de un perro”, en Cuentos completos. Trad. de José Rafael Hernández Arias. Madrid: Valdemar, 2000, pp. 346-376.

Mujica Lainez, Manuel. Cecil. Buenos Aires: Editorial Sudamericana, 1975.

— "Momentos de una amistad. Cartas a Victoria Ocampo", Revista Sur, (Homenaje a Manuel Mujica Lainez (1910-1984)) (1986), pp. 61-99.

Lejeune, Philippe, “Le pacte autobiographique (1973)”, en Francisco Jurado Arrones (dir.). El pacto autobiográfico y otros ensayos. Madrid: Megazul-Endymion, 1994a, pp. 4987.

— “La autobiografía en tercera persona (De “Je est un autre. L'autobiographie, de la littérature aux médias”), en Francisco Jurado Arrones (dir.). El pacto autobiográfico y otros ensayos. Madrid: Megazul-Endymion, 1994b, pp. 89-121.

— “El pacto autobiográfico 25 años después”, en Celia Fernández Prieto y M Mángeles Hermosilla Álvarez (eds.). La autobiografía en España: un balance. Madrid: Visor, 2004, pp. 159-172.

Marías, Javier, “Aquí me paro”, Ínsula, 799-800 (2013), pp. 55-56.

Martin, Adrienne L., "Berganza, comediante: el animal escénico en el Siglo de Oro”, Ínsula, 799-800 (2013), pp. 28-31.

Pérez-Reverte, Arturo, “No compres ese perro", en Perros e hijos de perra. Barcelona: Alfaguara, 2014, pp. 117-123.

Piña, Cristina, "Historia, realidad y ficción en la narrativa de Manuel Mujica Lainez", Revista Sur. Homenaje a Manuel Mujica Lainez (1910-1984), 358-359 (1986), pp. 173186.

Pozuelo Yvancos, José María y Rosa María Aradra. Teoría del Canon y Literatura Española. Madrid: Cátedra, 2000.

Pozuelo Yvancos, José María. De la autobiografía. Teoría y Estilos. Barcelona: Crítica, 2006.

Quesada Portero, Raúl. “Bomarzo” y el autobiografismo en la narrativa de Manuel Mujica Lainez. Granada: Universidad de Granada, 2010.

Rabell, Carmen. Lope de Vega: El arte nuevo de hacer "novellas". Londres: Támesis, 1992.

Recio Vela, Rafael, “Las fantasía de Mujica y Roa. Tras el escrutinio cervantino”, Espéculo. Revista de Estudios Literarios, 31 (2005).

Rey Hazas, Antonio. Deslindes de la novela picaresca. Málaga: Universidad de Málaga, 2003.

Roffé, Reina, “Entrevista a Manucho (1977)”, Cuadernos Hispanoamericanos, 689 (2007), pp. 107-116.

Ruiz Pérez, Pedro, "Venteando la novela”, en Julián Jiménez Heffernan (ed.). La tropelía. Hacia “El coloquio de los perros”. Tenerife: Artemisa Ediciones, 2008, pp. 379-427.

—_Sátira, picaresca, novela”, Ínsula, 778 (2011), pp. 10-12.

Sáez, Adrián J., "Más sobre Cervantes, Plutarco y los cínicos: una anécdota de Alcibíades y el Coloquio de los perros”, Anales Cervantinos, XLVI (2014), pp. 149-160.

Salinas, Pedro. "Defensa de la minoría literaria”, en Ensayos Completos. Ed. de Solita Salinas de Marichal. Madrid: Taurus, II, 1981, pp. 360-401.

Schanzer, George O. The Persistence of Human Passions: Manuel Mujica Lainez's Satirical Neo-Modernism. Londres: Tamesis Books, 1986.

Stevenson, Robert Louis, "El temperamento de los perros”, en Vivir. Madrid: Páginas de Espuma, 2015, pp. 225-238.

Unamuno, Miguel de. "Manual de Quijotismo"; "Cómo se hace una novela”; Epistolario cruzado Miguel de Unamuno y Jean Cassou (1921-1933); Censura y retórica de la cólera en el diario éxtimo del exilio. Ed. de Bénédicte Vauthier. Salamanca: Ediciones Universidad de Salamanca, 2005. 
Valdés, Juan de. Diálogo de la lengua. Ed. José Enrique Laplana Gil. Madrid: Crítica, 2010.

Vázquez, María Esther. El mundo de Mujica Lainez. Buenos Aires: Editorial de Belgrano, 1983.

Villanueva, Darío, "Narratario y lectores en la evolución formal de la novela picaresca”, en El polen de ideas. Barcelona: Promociones y Publicaciones Universitarias, 1991a, pp. 131-160.

— “Para una pragmática de la autobiografía”, en El polen de ideas. Barcelona: Promociones y Publicaciones Universitarias, 1991b, pp. 95-114.

— “Realidad y ficción: la paradoja de la autobiografía”, en José Romera, Alicia Yllera, Mario García-Page y Rosa Calvet (eds.). Escritura autobiográfica. Madrid: Visor, 1993, pp. 15-31.

Villena, Luis Antonio de, “Inicio de la exploración del país: Mujica Lainez”, Insula, 340 (1975), p. 3.

—“Entrevista. Manuel Mujica Lainez, entre la literatura y la vida”, Ínsula, 392-393 (1979), pp. 1 y 22.

—_En la muerte de Manuel Mujica Lainez. Recordando a “Manucho”“, Ínsula, 450 (1984), p. 10. 